\title{
GEOCHEMICAL NORMALIZERS APPLIED TO THE STUDY OF THE PROVENANCE OF LITHOGENIC MATERIALS DEPOSITED AT THE ENTRANCE OF A COASTAL LAGOON. A CASE STUdy In AVEIRo LAgOON (PORTUgal)
}

\begin{abstract}
Maria Virgínia Alves Martins ${ }^{1,2 *}$, Márcia Andréia da Silva Nunes ${ }^{1}$, Marcio Inacio Alves ${ }^{1}$, Marco Helenio de Paula Alves Coelho ${ }^{1}$, Wellen Fernanda Louzada Castelo ${ }^{3}$, LuCia Maria Lorini ${ }^{4}$, Denise Terroso ${ }^{2}$, Mauro César GERALDES ${ }^{1}$, LAZARO LAUT ${ }^{4}$, NOUREDDINE ZAABOUB ${ }^{5}$ AND FERNANDO ROCHA ${ }^{2}$
\end{abstract}

1 Universidade do Estado do Rio de Janeiro, Faculdade de Geologia, Rio de Janeiro, Brazil.

2 Universidade de Aveiro, Dpto. Geociências, GeoBio'Tec, Aveiro, Portugal.

3 Universidade Federal Fluminense, Niterói, Rio de Janeiro, RJ, Brazil.

4 Universidade Federal do Estado do Rio de Janeiro - UNIRIO, Instituto de Biociências, Rio de Janeiro, Brazil.

5 Institut National des Sciences et Technologies de la Mer, Salammbô, Tunis, Tunisia.

*Corresponding Author, virginia.martins@ua.pt

Received on 4 May 2018

Received in revised form on 5 June 2018

Accepted on 10 June 2018

Editor: Deniz, Ayas, Mersin University, Turkey
Citation:

Alves Martins, M.V., Nunes, M.A.S., Alves, M.I., Coelho, M.H.P.A., Castelo, W.F.L., Lorini, L.M., Terroso, D., Geraldes, M.C., Laut, L., Zaaboub, N., Rocha, F., 2018. Geochemical normalizers to study the lithogenic input to a coastal lagoon with hydrodynamic contrasts. A case study of Aveiro Lagoon (Portugal). Journal of Sedimentary Environments, 3 (2): 74-92.

\section{Abstract}

The use of geochemical normalizers has been applied in sedimentological studies in several study contexts, such as pollution, diagenetic and provenance assessment. Selected textural and mineralogical data of 137 surface sediment samples were compared by statistical analyses with geogenic elements concentrations normalized by the $\mathrm{Al}, \mathrm{Be}, \mathrm{Ce}, \mathrm{Fe}$, $\mathrm{Fe}+\mathrm{Al}, \mathrm{Li}, \mathrm{Rb}$ and $\mathrm{Sc}$ aiming to identify the best normalizer to trace different sources of bottom sediments for the Aveiro Lagoon entrance (NW of Portugal). The study area is heterogenous in terms of hydrodynamics and sedimentary processes.

The most commonly applied geochemical normalizer for the sediments elemental concentrations has been the aluminum. However, the statistical analyses evidenced that the best normalizer was the scandium, since Principal Components Analysis results have evidenced that the element/Sc values are largely independent of sediment granulometry and thus have allowed the identification of compositional differences not related to grain size. Statistical analyses have also allowed to discriminate groups of stations that: i) trace the entry and exit of mixed sources sediments of the lagoon due to the action of tidal currents; ii) contain materials provided from the erosion of granitoids present mainly along the Douro River basin, located to the north, and transported southward by coastal drift; iii) encompasse sediments provided from the erosion of the Schist-Greywacke Complex crossed by the Vouga River that drains into the inner central zone of the lagoon and; iv) represent an area of sediment accumulation located near the entrance of Mira Channel, where lithogenic materials, provided by mixed lithologies in addition to organic matter, are being deposited. The results of this work contribute to the knowledge of the sedimentary dynamics of the Aveiro Lagoon, a coastal system which is part of a littoral stretch that is being strongly eroded, due to natural and anthropic causes and should be applicable to other coastal systems with similar characteristics.

Keywords: Sedimentary dynamic. Sediment sources. Geogenic elements. Statistical analyses. Interpolation estimations. Kriging. Mapping. 


\section{Introduction}

The human population has made innumerable changes in the ecosystems around the world aiming to adapt the environment to people's needs. The coastal zones are no exception. They have been suffering strong anthropic interventions, related, for instance, to the development of human settlements, installation of ports and/or industries and dredging activities (Barbier et al., 2008; Martínez et al., 2017). As a consequence, several geomorphological changes are modifying the sedimentary dynamics in coastal zones (Pethick and Crooks, 2000; Burningham and French, 2017) and the pollutants accumulation is damaging the natural ecosystems (Clark, 2001; Ducrotoy et al., 2000; Grant and Briggs, 2002). The use and occupation of coastal zones around the world require a better knowledge of the effects of both periodic (short) changes, such as storm events, as well as the longer ones such as changes of energetic sea action depending on climatic oscillations and human interventions or even the geological framework. These factors may influence the coastal morphology (Godschalk, 2009; Chang et al., 2018).

The Aveiro region (Center of Portugal) is also being marked by different types of anthropogenic interventions, such as the Aveiro Port, several industries on the river and the lagoon margins such as the Estarreja Chemical Complex (Pereira et al., 1998; Bastos et al., 2012; Rodrigues et al., 2016). Biotic and sedimentological studies in the area showed enrichment of pollutants, such as $\mathrm{Hg}, \mathrm{Cr}, \mathrm{Zn}$ and $\mathrm{Pb}$, in the surface sediments, both in the lagoon mouth and in the most confined areas (e.g. Pereira et al., 1998; Martins et al., 2015, 2017). The anthropogenic interventions also directly or indirectly altered the sedimentary dynamics in the Aveiro Lagoon which is characterized by the constant entry and exit of sedimentary material over time through the inlet and rivers' discharge into the inner lagoonal areas (Lopes et al., 2006; Plecha et al., 2010).

The morphodynamics in the Aveiro lagoon depends on oceanic conditions (Plecha et al., 2012). During autumn and winter, the oceanic surface circulation is predominantly directed to the north induced predominantly by south winds (Frouin et al., 1990, Haynes and Barton, 1990; Mazé et al., 1997; Huthnance et al., 2002). However, on the coast, near the bottom, there is a flow to the south, resulting from the maritime agitation from west (coastal drift).

In spring and summer regimes, as a result of the migration of the Azores Anticyclone to the north and the weakening of the Icelandic Low-Pressure Center, the $\mathrm{N}$ and NW winds are predominant (Wooster et al.,1976; Fiúza et al., 1982; Silva, 1992). The circulation pattern associated with the spring/summer regime is characterized by the development of a superficial flow towards the south (Fiúza et al., 1982), favoring the transport of sediments from north to south.

It is supposed that the sediments deposited at the Aveiro Continental shelf are mainly supplied by the Douro River (at
North) and the Mondego River (at South) but the net balance of sediment transport along the coast to the studied region should be from north (Abrantes et al., 2015).

It is presumed that sediments provided from different source areas are deposited in Aveiro lagoon. Previously, Martins et al. (2016) using available concentrations of rare earth elements (REE) in several sedimentological phases identified different sources of sediments through the Aveiro Lagoon channels.

The normalization of elemental content using an immobile element is commonly applied in geochemical studies for correcting grain-size effects and dilution by sedimentary phases such as carbonates and silica (Sakan et al., 2011). This type of data processing may also reveal possible sediment enrichment in trace metals. Presently, Al is the most frequently used geochemical normalizer in sediments, assuming that this element is held exclusively in terrigenous aluminosilicates (Karageorgis et al., 2009).

The present study intends to apply the most convenient geochemical normalizer to identify different sources of sediments that are being received in the Aveiro Lagoon entrance. It is a difficult task since this region displays strong hydrodynamic contrasts and complex sedimentary processes.

\section{Study Area}

The Aveiro Lagoon (also known as Ria de Aveiro) is located at the Atlantic coast of Portugal (Fig. $1 \mathrm{~A}$ ). It is considered one of the largest geographical accidents and the most important one in Portugal, functioning as a multiestuary, since it receives several rivers and streams. It is an integrant part of the Vouga River hydrographic basin, the largest one of this region. The Vouga River springs at 930 meters of altitude, in the Serra da Lapa, located in the interior center of Portugal. When entering the Aveiro Region, due to the low land slope, this river branches before it disembogues into the lagoon.

The Ria de Aveiro is approximately $45 \mathrm{~km}$ long and 11 $\mathrm{km}$ east-west wide and is composed by several channels, surrounding islands and islets radiating from their artificial mouth, which is its only link to the ocean. The lagoon hydrodynamics is mostly controlled by tides (Dias et al., 1999). It has a semi-diurnal tidal regime, with amplitude varying from $<1 \mathrm{~m}$ in the low tide of quadrature to $4 \mathrm{~m}$ in the syzygy tide and low water-river regime entering the lagoon (Dias et al., 2000, 2001; Lopes and Dias, 2015). The lands drained by the fluvial network that flows into the Ria de Aveiro present varied lithology (Pérez-Estaún et al., 2004).

The center of Portugal is almost exclusively located in the Central Iberian Zone (Fig. 1A), which is characterized by the presence of levels of quartzites interlayered with shales (Cambrian and Upper Precambrian, Hispanian), denominated Schist-Greywacke Complex (Ribeiro et al., 
1979). It is also characterized by a regional Hercynian multiphase tectonic and metamorphic evolution, closely related to granitoid intrusions (Teixeira, 1981). The synorogenic magmatism of the Central Iberian Zone comprises mainly granitoids of the alkaline and calcoalkaline series. The alkaline series are characterized by the presence of albite and/or oligoclase and apatite and by the predominance of two micas (muscovite and biotite).
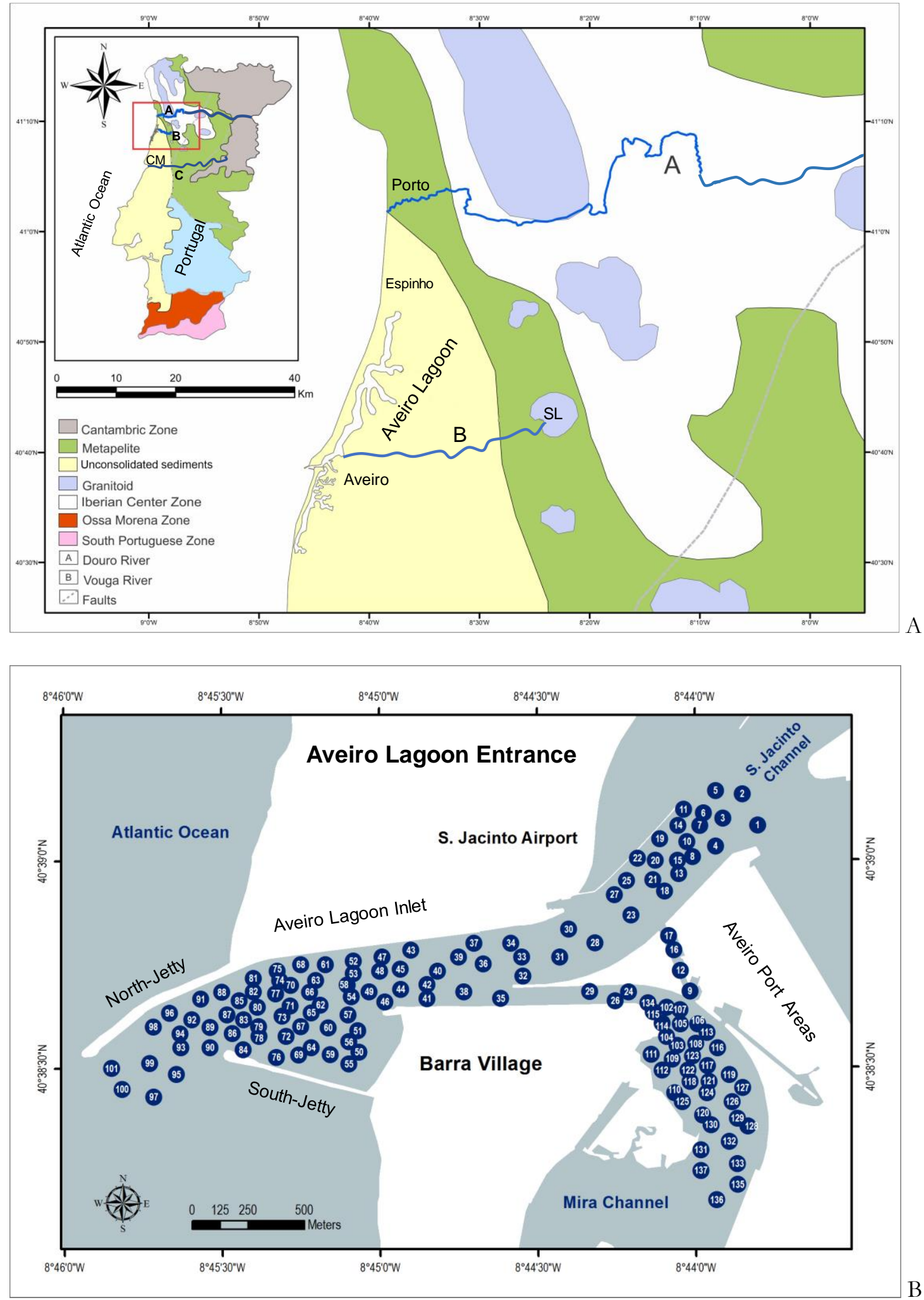

Fig. 1. Study area. A. Geologic scheme of Portugal (adapted from Pérez-Estaún et al., 2004) and the study area. B. Samples location in the Aveiro Lagoon entrance area. 
The calco-alkaline series have the following characteristics: plagioclase of oligoclase-andesine composition, predominant biotite on muscovite, common basic precursors and abundant microdioritic enclaves, with mesocratic character, and varied accessory minerals among which are titanite, apatite and opaque (Ferreira, 2000). Carbonate formations consisting of limestones, dolomitic limestones, limestones and marl (Barbosa, 1981), from the Cretaceous sedimentary series, also occurs in the adjacent continental area, for instance, in Salreu-Taboeira-AzurvaFermentelos-Vilarinho do Bairro and in the vicinity of Fermentelos (Rocha and Gomes, 1992).

The lagoon development, on the other hand, is quite recent. Its development should have begun at about a thousand years (Lillebo et al., 2011). The stabilization of the sea level close to the present, between 5,000 and 3,000 years $\mathrm{BP}$, has led to the silting up of the estuaries and the growth of sandy spits (Dias, 1987; Rodrigues and Dias, 1989). In the $20^{\text {th }}$ century, the coast between Espinho and Cape Mondego formed a gulf (Amaral, 1968). The mouth of the Vouga River was then $20 \mathrm{~km}$ into the coast. At the south of Espinho, there was only a sandy spit, which progressed southward, linking to the sands of Mira, in the middle of the $18^{\text {th }}$ century. Thus, the individualization of the Ria de Aveiro was related to the formation of a barrier island (Cunha, 1930; Neves, 1935; Girão, 1941; Martins, 1947; Abecassis, 1954), which was formed from the development of two sandy spits which grew from north to south and from south to North, isolating the sea from the direct contact with the Vouga River, which until then drained into the North Atlantic (Rocha et al., 2005). Thus, with the closure of this direct contact between the sea and the mainland, both water and sediment exchanges between the continental shelf and the Ria de Aveiro were reduced and controlled by the narrow São Jacinto Channel and the Aveiro lagoon inlet.

The Aveiro region is densely populated with important administrative, commercial and industrial activities to the country. The Aveiro Lagoon has undergone a series of anthropogenic interventions, such as the construction of the Aveiro Port, constant changes in the channels configuration especially the dredging of the canals and the extension of the jetties to facilitate navigation (Plecha et al., 2010). It is located in a littoral sector, where there is a noticeable tendency for a strong retreat of the coastline marked by the decrease of the beaches width and the dunes migration towards the continent (Lira et al., 2016; Stronkhorst et al., 2018).

\section{Materials and methods}

This work is based on the analysis of 137 bottom sediment samples (Fig. 1 B), collected in the Ria the Aveiro mouth area. As the velocity of the tidal currents in the lagoon inlet and in the $\mathrm{S}$. Jacinto Channel is very strong, the samples were collected in high and low slack water phases, when theoretically the flood and the ebb flow, respectively, stops. Once the slack water phases are short, the samples were collected at several sampling events in 2006 and 2007. The positions of all samples were determined by GPS for geostatistical analysis. For samples location, WGS84 projection and Universal Transverse Mercator (UTM) zone $29 \mathrm{~N}$ coordinates were used (Appendix 1). Sediment samples were collected with an adapted small Ponar ${ }^{\circledR}$ Grab opened in two apertures. The upper aperture was used to scrape the first $2 \mathrm{~cm}$ of the surface sediments.

Before to be submitted to textural, mineralogical and geochemical analyses, the sediment samples were oven-dried at $65{ }^{\circ} \mathrm{C}$ during about $72 \mathrm{~h}$. The samples were quartered and a portion of about $250 \mathrm{~g}$ of sediment was used for particle size analyses. Grain size analysis was performed using the classic sieving method. The initial weight of the samples was recorded. Fine fraction was separated from the coarser one by wet sieving, using a sieve of $63 \mu \mathrm{m}$ screen. Both sedimentary fractions were oven dried and weighed. Coarser sediment fractions $(>63 \mu \mathrm{m})$ were separated using a sieve column with the following dimensions: $2000 \mu \mathrm{m}, 1000 \mu \mathrm{m}$, $500 \mu \mathrm{m}, 250 \mu \mathrm{m}$ and $125 \mu \mathrm{m}$. The dry weight of each sediment fraction was recorded and its percentage was determined. The sedimentological parameters were determined using the Gradistat software (Blott and Pye, 2001), according to the methodology of Folk and Ward (1957).

Total organic matter $(\mathrm{OM})$ was determined in a portion of sediment split $<2000 \mu \mathrm{m}$, from each sample. About $5 \mathrm{~g}$ of dry sediment were oven-dried at $105^{\circ} \mathrm{C}$ for $8 \mathrm{~h}$. Samples were cooled in a desiccator and weighed before they were combusted at $450{ }^{\circ} \mathrm{C}$ for $8 \mathrm{~h}$ in a muffle furnace, according to Oliver et al. (2001). After combustion, the samples were cooled in a desiccator and weighed again. The OM values were reported as percentages of dry weight sediment and were estimated by the following equation: $\mathrm{OM}=[$ (oven-dry sediment weight - sediment weight after combustion)/ovendry soil weight] $\times 100$.

A sediment split $<2000 \mu \mathrm{m}$ of each sample was milled in a mechanical agate mill and used for mineralogical and geochemical analyses. The mineralogical results were obtained through X-ray diffraction (XRD) techniques. For the preparation of non-orientated powders, about $0.5 \mathrm{~g}$ of disaggregated sediment was placed with the minimal compression on a standard aluminum sampler holder. The mineralogical composition of the sediments was studied through XRD on a Philips $\mathrm{X}^{\prime}$ Pert PW3040/60 diffractometer, using $\mathrm{Cu}-\mathrm{K} \alpha \mathrm{X}$-ray radiation and software $\mathrm{X}$ Pert 2.0. Scans were run between $2^{\circ}$ and $40^{\circ} 2 \mathrm{q}$. The minerals semi-quantification followed the methodology described by Martins et al. (2007). The percentage of halite 
was determined but not considered in this work, since this mineral may result from the chemical precipitation of salts during the preparation of the sediment samples for analysis.

Elemental concentrations were determined by ICP-MS (Inductively Coupled Plasma-Mass Spectrometer) analysis, after acid digestion at ACME Analytical Laboratories, Canada according to US Environmental Protection Agency (USEPA) Method SW-846 3052 (USEPA 1996) and Method SW-846 6020A (USEPA 2007) and Dutton et al. (2013). The elemental concentrations of 29 chemical elements were used in this work (Appendix 1).

The geochemical partition of certain substances consists of the determination of distinct compounds in which the element is bound under different degrees of ionic bond strength to different sedimentary phases (Salomons and Stigliani, 1995). It has as an auxiliary function in the identification of sources as well as in the prognosis when possible of the occurrence of sediment remobilization (Schiff and Wiesberg, 1999).

In geochemical studies of provenance there is a difficulty in distinguishing what comes from a lithologic contribution or derives from an anthropic origin. Hence the use of normalizers that are chemical elements present in the chemical composition of regional rocks and have a conservative character or have relatively constant natural concentrations in the lithogenic matrix during meteorism and transport processes, and which do not receive major influences from variables such as oxy-reduction, radioactive decay, isotope fractionation and atmospheric changes and diagenetic processes is useful (Chester, 1990).

Loring (1990) observed that grain size is a significant factor in the variability of trace metals in sedimentary deposits and that, for this reason, there is a need for normalization procedures of the analyzed components with a conservative element that varies with the granulometric changes. Based on Herut and Sandler (2006) and references herein, several geochemical normalizers have been applied aiming to reduce the grain size influence in the environment and to give indication of pollution and the regional lithogenic contribution to studied areas.

In order to identify the most adequate normalizer and to analyze the geogenic contribution to Aveiro Lagoon entrance area, the element ratios with $\mathrm{Al}, \mathrm{Be}, \mathrm{Ce}, \mathrm{Fe}, \mathrm{Fe}+\mathrm{Al}$, $\mathrm{Li}, \mathrm{Rb}$ and $\mathrm{Sc}$ (in denominator) were compared with granulometric and mineralogical variables by statistical analyses. Concentrations of rare-earth elements (REE) are generally normalized to the composition of the upper continental crust, such as the North American Shales Composite (NASC; Rudnick and Gao, 2003) or the European Shales (ES; Haskin and Haskin, 1966). In this work $\mathrm{La}$ and $\mathrm{Ce}$ (REE) and associated elements, $\mathrm{Y}$ and Sc, were also normalized by the composition of the upper continental crust (Rudnick and Gao, 2003), since most of the sediments found in the study area are sandy. Other element ratios, such as $\mathrm{Nb} / \mathrm{Ta}$, $\mathrm{Th} / \mathrm{U}, \mathrm{K} / \mathrm{U}$ and $\mathrm{La} / \mathrm{Ta}$, also were used to trace changes in the sediment sources.

\subsection{Statistical Analyses}

Selected textural, mineralogical and geochemical data were transformed by $\log (\mathrm{x}+1)$ before to be submitted to R-mode Cluster Analysis (CA), based on Complete Linkage and 1-Pearson r correlation, and to Principal Components Analysis (PCA). CA was carried out in order to group the variables with general similar pattern of distribution in the study area and PCA to explain the variance-covariance structure of the studied data and to select the principal components with the largest variance. These statistical treatments were performed using a Statsoft software (Statistica 12). Concentrations of selected chemical elements were also compared by bi-plots and linear regression (with the Microsoft Excel software).

The studied data were also submitted to Q-mode Cluster Analysis using Euclidean distances and the Ward's method for the samples amalgamation. Data for Q-mode Cluster Analysis were transformed by square root of 0.5 to normalize. The PCord software was used in this analysis.

\subsection{Spatial interpolation}

Spatial interpolation is a method to estimate the data in contiguous area and forecast the values at unknown locations, i.e., where no measured values are available, using available observation data (Chai et al., 2011). The goal of spatial interpolation is to create a surface that is intended to best represent empirical reality (Azpurua and Ramos, 2010). The interpolation methods can be classified in two major groups: deterministic and geostatistical. Deterministic interpolation techniques create surfaces from measured points, based on either the extent of similarity or the degree of smoothing (Keblouti et al., 2012).

Geostatistical or stochastic interpolation techniques capitalize on the spatial correlation between neighboring observations to predict attributed values at unsampled locations (Goovaerts, 2000). These methods are not simply based on an estimation of the unknown value as a function of the distance. In addition to that, they implement the function of unknown spatial autocorrelation between the values of the sample points (Keblouti et al., 2012). In this study, the $\operatorname{ArcGis} \AA 10.3$ software was used to created surfaces applying four interpolation methods: three deterministic (IDW, Spline, Spline with Barriers) and one geostatistical (Kriging).

The ordinary Kriging was used in this study. The prediction of ordinary Kriging is a linear combination of measured values where the constant mean $(\mu)$ is assumed to be unknown (Borges et al., 2016).

Kriging is a geostatistical interpolation technique that provides a means of interpolating values for points not 
physically sampled using knowledge about the underlying spatial relationships in a data set to do so, where variograms provide this knowledge (Naoum and Tsanis, 2004). This method is based on regionalized variable theory which provides an optimal interpolation estimate for a given coordinate location, as well as a variance estimate for the interpolation value. Kriging encompasses an interactive investigation of the spatial behavior of the phenomenon before generating the output surface, using a variogram model to characterize spatial correlation (Naoum and Tsanis, 2004). A variogram describes, in terms of variances, how spatial variability changes as a function of distance and direction (Isaaks and Srivastava, 1989). Kriging depends on spatial and statistical relationships to calculate the surface, being a two-step process that begins with semivariance estimations and then performs the interpolation (Keblouti et al., 2012).

Model parameters setting and interpolation model test are quite important. Sensitivity analyses of varying setting parameters and models' choices of the three interpolation methods were performed in order to select the values that produced best fitting models and better resulting surfaces. For all interpolation techniques, the number of the nearest input sample points to be used to perform interpolation was set as 4, 6, 8, 10 and 12. For IDW, the power exponent of distance as 1,2 and 3 were tested. For Spline, the regularized and tension type was tested. Additionally, because the spline method disregards geographical barriers, the Spline with Barriers method was also tested. It treats the current gridbased surface model as an elastic membrane to achieve an approximation to a minimum curvature surface that considers both the input point data and discontinuities encoded in the barriers (Terzopoulos, 1988). For Kriging, the Spherical, Exponential and Gaussian semivariogram models were tested. The best combination of interpolation techniques and parameters was selected using $2 \mathrm{D}$ and $3 \mathrm{D}$ visualization analyses to compare the surfaces generated, screening for surfaces with good behavior and avoiding anomalies and unwanted patterns (e.g., sharp edges, "bullseyes"). Considering the dataset, the best surfaces produced for Aveiro Lagoon were those generated by the Spline with Barriers interpolation method.

\section{Results}

The textural, mineralogical and geochemical data were included in Appendix 1. The percentage of the sediment fractions $>2000 \mu \mathrm{m}$ (Fig. 2a) and $<63 \mu \mathrm{m}$ (Fig. 2b) were $<96 \%$ (mean 15\%) and $<94 \%$ (mean $6 \%$ ), respectively. The SMGS values ranged from 5-3660 $\mu \mathrm{m}$ (mean $603 \mu \mathrm{m}$ ). Mud to gravely sand were found in the study area, being sandy sediments the most common substrate. Coarser sediments, with high gravel fraction contents (Fig. 2a), were found along the S. Jacinto Channel and Aveiro Lagoon Inlet. Finer grained sediments exist mostly at the western side of Mira Channel and close to the South-Jetty (Fig. 2b).

Sorting values ranged from 1.1 to 4.0 (Fig. 2c), with most samples being "moderately sorted" to "well sorted". The highest sorting values were located in the Mira Channel and the lowest ones in the central zone of the S. Jacinto Channel and in the lagoon inlet. Skewness and kurtosis values varied from -0.80 to 0.64 and 0.51 to 4.1 (Fig. 2d), respectively. Most samples are bi or trimodal. The most common modes are $1200 \mu \mathrm{m}$ and $77 \mu \mathrm{m}$.

The sediments are essentially composed of the following minerals: quartz $(<91 \%$, mean $63 \%)$, phyllosilicates $(<50 \%$, mean $5 \%$; Fig. 2e), plagioclase ( $<42 \%$, mean $7 \%$; Fig. $2 \mathrm{f}), \mathrm{K}-$ feldspars $12 \%$; Fig. $2 \mathrm{~g})$, calcite $(<11 \%$, mean $2 \%$; Fig. $2 \mathrm{~h})$ and dolomite $(<6 \%$, mean $1 \%)$. Samples with higher percentage of phyllosilicates are located in the Mira Channel and near the North-Jetty. Relatively higher percentages of Kfeldspars were found at the Aveiro Lagoon inlet and at the eastern side of Mira Channel. Calcite contents increased in the center of Mira Channel.

Figure 3 presents the results of selected geochemical data. The OM content ranged from $0.01-9.75 \%$, being higher in the Mira Channel (Fig. 3a). The maximum, minimum and mean concentrations of the other analyzed chemical elements and the element ratios are given in Table 1. Aluminum concentrations were higher in Mira Channel and near the South-Jetty (Fig. 3b). A similar pattern was observed in the other analyzed elements.

\subsection{Statistical results}

The variation of the elemental, $\mathrm{OM}$ and mineral contents and textural data analyzed by R-mode Cluster Analysis (CA; Fig. 4), grouped the variables in two main clusters, depending on the sediment granulometry. Whereas SMGS and sediment fraction $>63 \mu \mathrm{m}$ are positively correlated with depth and quartz (Cluster 1), all the other variables are more related to fine grained sediments (Cluster 2). These two main groups agree with the correlations presented in Appendix 2.

In cluster 2 (CA; Fig. 4), four sub-clusters can be considered: Sub-Cluster 2.1 with fine fraction, OM, phyllosilicates, sorting, S and Mo; Sub-Cluster 2.2 with the analyzed chemical elements, except $\mathrm{Ca}$ and $\mathrm{Sr}$; Sub-Cluster 2.3 with $\mathrm{Ca}$, Sr, calcite, dolomite; Sub-Cluster 2.4 with skewness, kurtosis, K-feldspars and plagioclase. The regression lines of the biplots of $\mathrm{Zr}, \mathrm{Hf}$ and $\mathrm{Th}$ concentrations plotted against $\mathrm{Ce}, \mathrm{La}, \mathrm{Y}$ and Sc evidence the positive correlations between these elements (Fig. 5). Most of the other elements also have positive correlations with each other as revealed by Cluster Analysis (Fig. 4). 

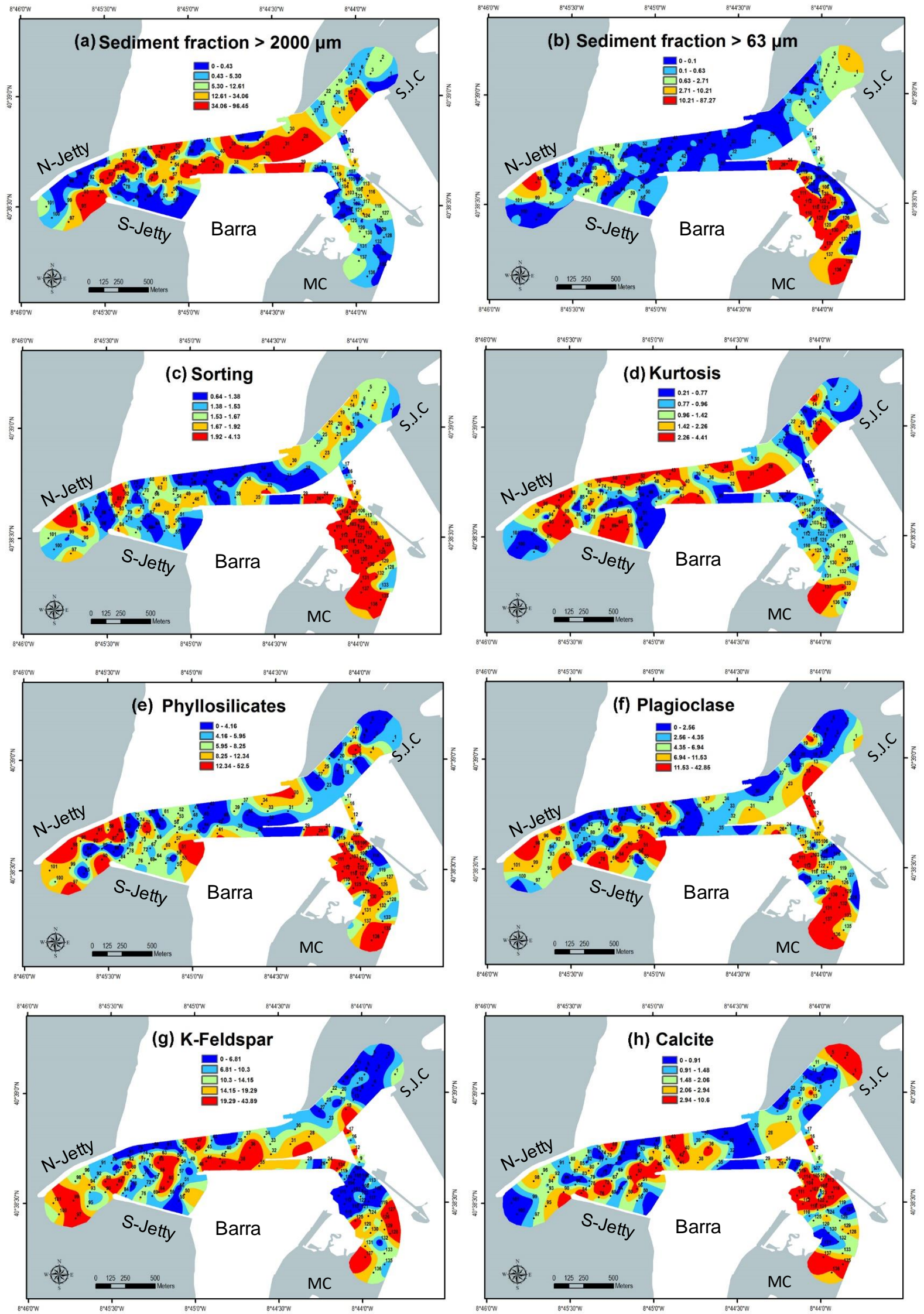

Fig. 2. Maps of distribution of the following variables: a) sediment fraction $>2000 \mu \mathrm{m}(\%)$; b) sediment fraction $<63 \mu \mathrm{m}(\%)$; c) sorting; d) kurtosis; e) phyllosilicates (\%); f) plagioclase (\%); g) K-feldspars (\%); h) calcite (\%). 

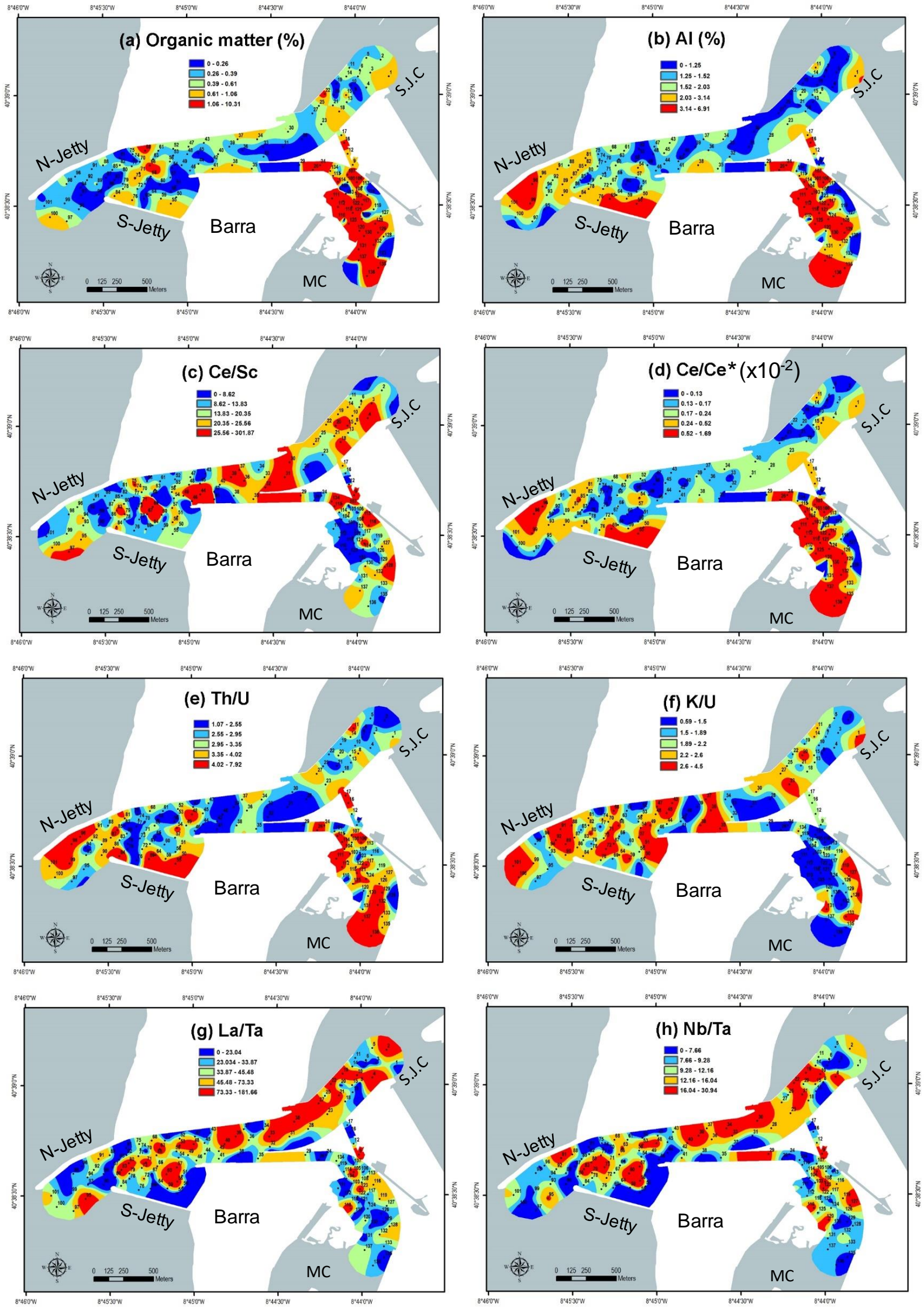

Fig. 3. Maps of distribution of: a) Organic Matter (\%); b) Al (\%); c) Ce/Sc; d) Ce/Ce*; e) Th/U; f) K/U; g) La/Ta and; h) Nb/Ta. The asterisks $(*)$ indicate that Ce was normalized by the respective upper continental crust composition (according to Rudnick and Gao, 2003). 


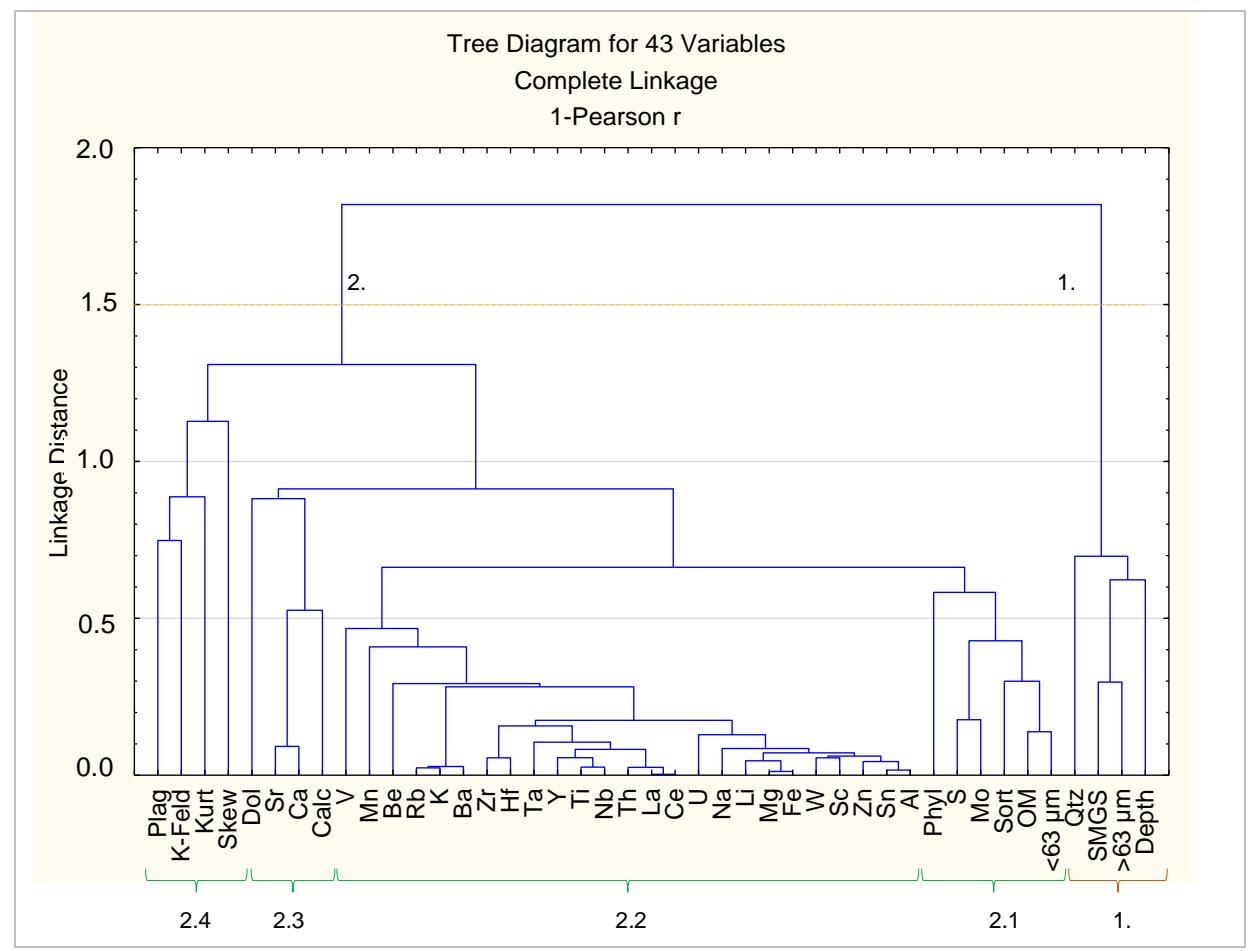

Fig. 4. Results of R-mode Cluster Analysis based on the analyzed variables. Legend: $>63 \mu \mathrm{m}$ - sand fraction; SMGS - sediment mean grain size; Qtz - quartz; <63 $\mu \mathrm{m}$ - fine fraction; OM - organic matter; Sort - sorting; Phyl - phyllosilicates; Calc - calcite; Dol - dolomite; Skew- skewness; Kurt - kurtosis; K-Feld - K-feldspars; Plag - plagioclase.

The total explained variability for the Factor 1 and Factor 2 of the PCA (Appendix 3), based on the normalized elements (with $\mathrm{Al}, \mathrm{Be}, \mathrm{Ce}, \mathrm{Fe}, \mathrm{Fe}+\mathrm{Al}, \mathrm{Li}, \mathrm{Rb}$ and $\mathrm{Sc}$, in denominator) and the other analyzed variables (depth, fine fraction, SMGS, sorting, quartz, K-feldspars, plagioclase, calcite, dolomite, phyllosilicates and OM values), were different depending on the normalizer. The total explained variability of the Factors 1 and 2 of that PCA (based on the mentioned variables) was for the following normalizers: $\mathrm{Al}$ $=0.52 \% ; \mathrm{Be}=0.65 \% ; \mathrm{Ce}=0.46 \% ; \mathrm{Fe}=0.58 \% ; \mathrm{Fe}+\mathrm{Al}=$ $0.50 \% ; \mathrm{Li}=0.50 \% ; \mathrm{Rb}=0.56 \%$ and; $\mathrm{Sc}=0.70 \%$. Thus, the total explained variability of the Factors 1 and 2 was highest for $\mathrm{Sc}$ used as geochemical normalizer.

The biplot of Factor 1 against the Factor 2 for the element/Sc ratios and the other analyzed variables (depth, fine fraction, SMGS, sorting, quartz; K-feldspars, plagioclase, calcite, dolomite, phyllosilicates and $\mathrm{OM}$ values) shows that the geochemical ratios are no longer subordinated to the fine fraction of the sediments (Fig. 6).

The results of the PCA for the two first factors (Appendix 3), based on the values of: a) Be normalization is similar to those obtained with the normalization with Sc but the correlations (Appendix 4) show that the element/Be values have positive correlations with fine fraction, this is, they are yet linked with the sediment grain size; b) the element/Fe ratios are associated with coarser sediments (SMGS and quartz); c) element/Rb, element/Al, element $/ \mathrm{Fe}+\mathrm{Al}$ and element/Li ratios are associated with fines; d) element/Ce ratios are in part positively correlated with fines and in part with coarse sediments.

According to the PCA of Fig. 6, most of the element/Sc values, except $\mathrm{V} / \mathrm{Sc}$, have similar patterns of distribution. Hence some of these variables, such as $\mathrm{Ce} / \mathrm{Sc}, \mathrm{La} / \mathrm{Sc}$, $\mathrm{Th} / \mathrm{Sc}, \mathrm{Al} / \mathrm{Sc}, \mathrm{Zr} / \mathrm{Sc}, \mathrm{Rb} / \mathrm{Sc}$ and $\mathrm{V} / \mathrm{Sc}$, were used in a $\mathrm{Q}-$ mode Cluster Analysis (Fig. 7) jointly with other variables such as: $\mathrm{La} / \mathrm{La}^{*}, \mathrm{Ce} / \mathrm{Ce}^{*}, \mathrm{Y} / \mathrm{Y}^{*}$ and $\mathrm{Sc} / \mathrm{Sc}^{*}$ (normalized elements by the respective upper continental crust composition), $\mathrm{Nb} / \mathrm{Ta}, \mathrm{La} / \mathrm{Ta}, \mathrm{Th} / \mathrm{U}, \mathrm{K} / \mathrm{U}$, depth, fine fraction, SMGS, sorting, quartz, K-feldspars, plagioclase, calcite, dolomite, phyllosilicates and $\mathrm{OM}$ values. The results of Q-mode Cluster Analysis allowed the identification of five groups of stations mapped in Fig. 8. The mean values of the analyzed variables for each group of stations are presented in Table 2. Each group of stations is distinguished by different mean values of the analyzed variables.

\section{Discussion}

\subsection{General sedimentological characteristics of the study area}

The increase of coarser sediment fractions $(>63 \mu \mathrm{m})$ determines the rise of SMGS. Both variables are positively correlated and are associated with depth (CA in Fig. 4 and correlations in Appendix 2) where tidal currents activities are stronger (reaching velocities $>2 \mathrm{~m} / \mathrm{s}$ ) in the study area (Vaz et al., 2005). Thus, the granulometric characteristics of the sediments are closely related to the hydrodynamics at the lagoon entrance. 

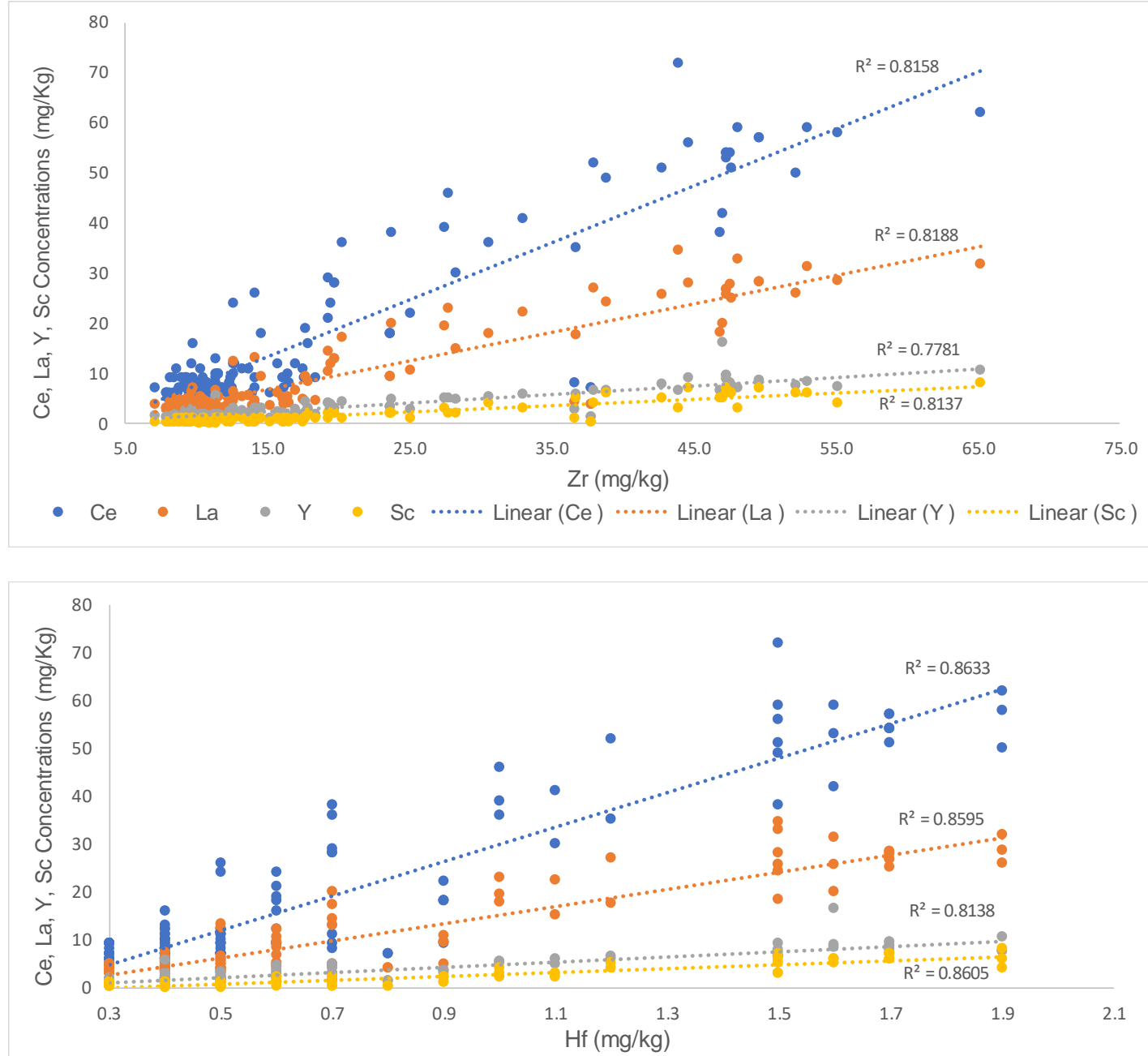

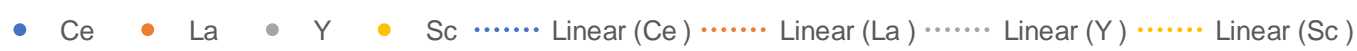

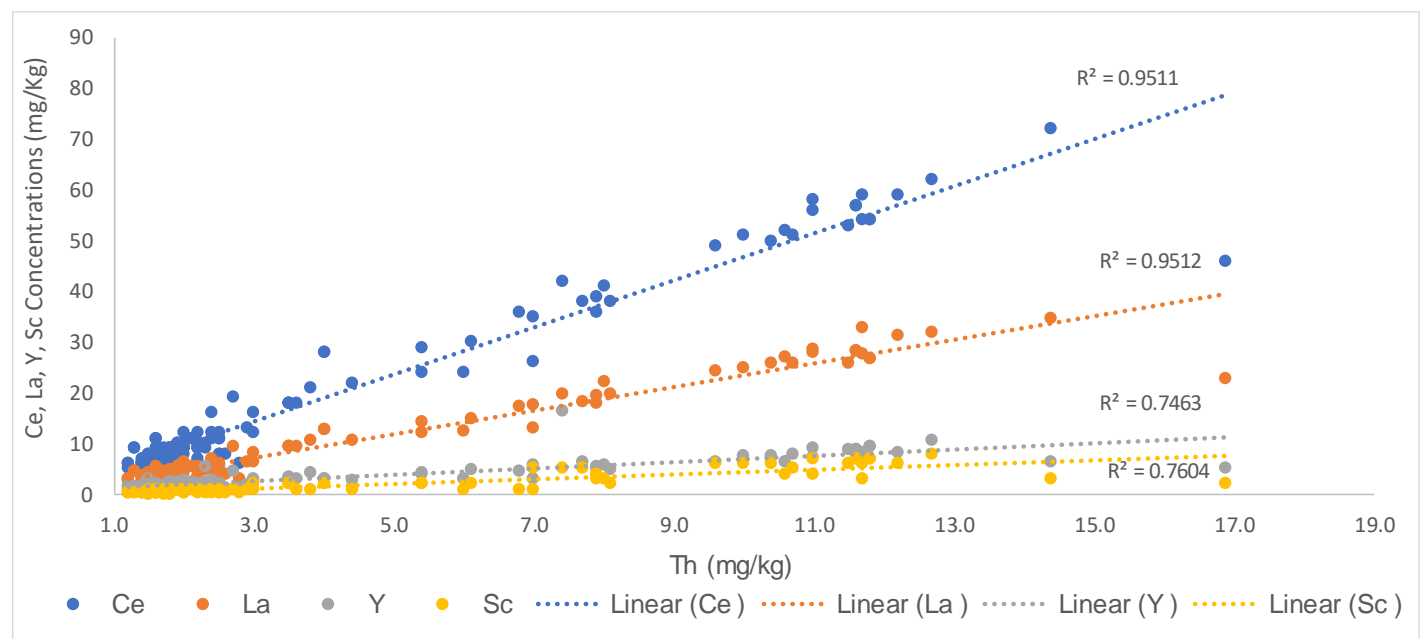

Fig. 5. Concentration of Zr, Hf and Th vs. Ce, La, Y and Sc. The regression lines evidence positive correlations between Zr, Hf and Th and REEs and Sc. 


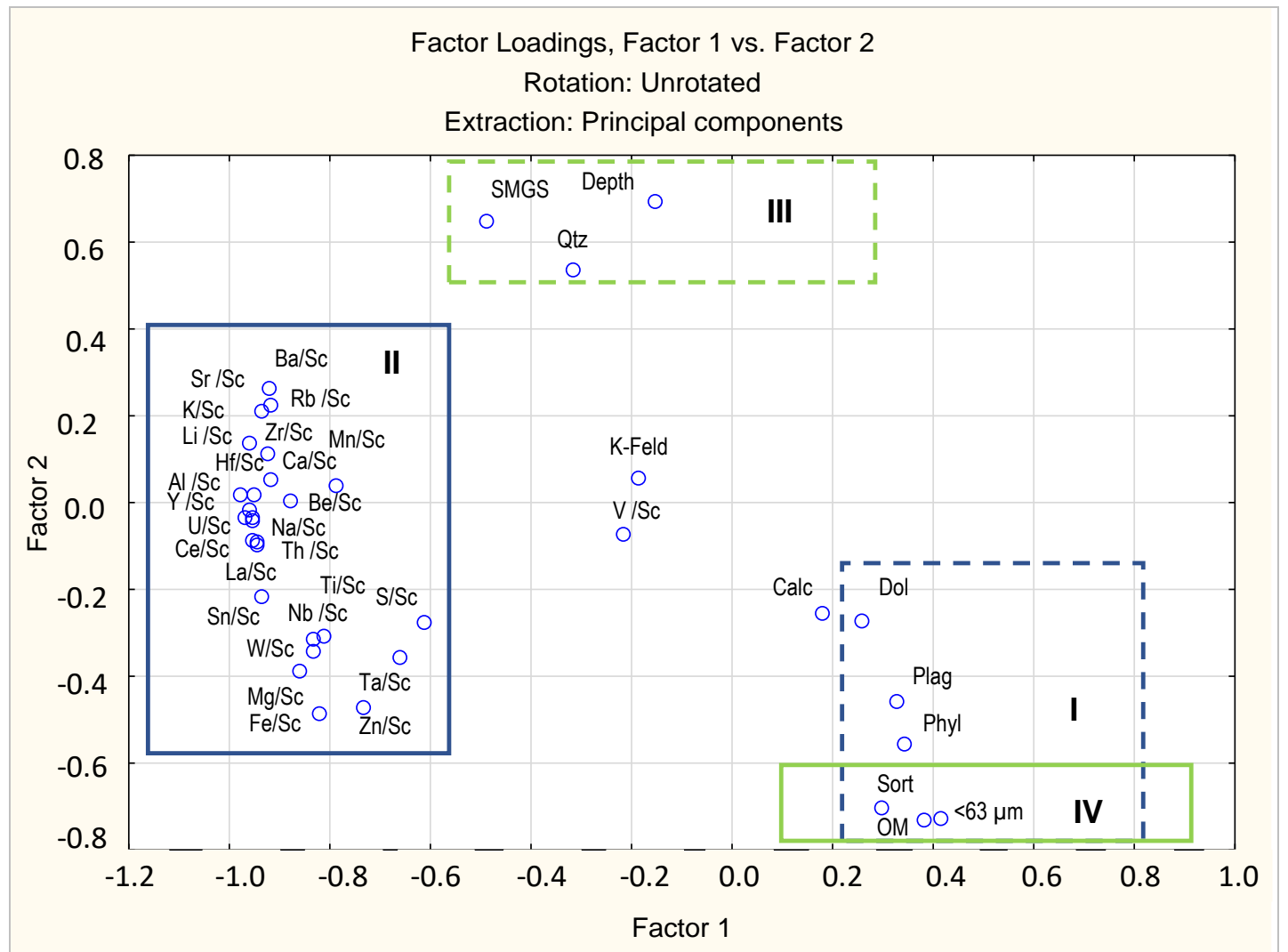

Fig. 6. Biplot of Factor 1 against the Factor 2 of PCA based on element/Sc ratios against other variables. Legend: SMGS - sediment mean grain size; Qtz - quartz; <63 $\mu \mathrm{m}$ - fine fraction; OM - organic matter; Sort - sorting; Phyl - phyllosilicates; Calc - calcite; Dol dolomite; K-Feld - K-feldspars; Plag - plagioclase.

The distribution pattern of sediment fractions $>2000 \mu \mathrm{m}$ and $<63 \mu \mathrm{m}$ (Fig. 2a, b) indicates that the zones with the strongest bottom currents are located along the S. Jacinto Channel and the Aveiro Lagoon inlet. The sediments are more poorly sorted in the western side of the Mira Channel which corresponds to a sandy mud bank associated with a tidal plain. The sorting values in this zone are a consequence of the semidiurnal tides effect on a low depth area (from a subtidal to intertidal zone). This region is also located near the Barra Village, where anthropogenic materials are released.

The distribution of skewness values reveals that the granulometric characteristics are quite heterogeneous, as a result of the bottom irregularities and probably the presence of sand ripples and megaripples which may exhibit variations in terms of their wavelengths and grain-size distributions (Yizhaq et al., 2012). The presence of bi-to-polymodal sediments in most of the sites may be related to the deposition/removal of sedimentary loads by currents and should be related to irregularities of the bottom morphology and changes in the activity of the transport agent. However, the distribution of the kurtosis values also shows that sediments of the channel margins tend to be more heterogeneous than that of the center of the navigable channels, where the currents intensity seems to be more selective.
The coarsest sediments in the study area are essentially composed of quartz (CA of Fig. 4; Cluster 1). In less coarse sediments, plagioclase and $\mathrm{K}$-feldspars contents tend to increase (CA of Fig. 4; sub-cluster 2.4). Quartz is a mineral more resistant to erosion and reworking by hydrodynamic processes and, hence, its relationship with the coarser fraction of the sediments. In contrast, plagioclase and $\mathrm{K}$ feldspars are related to relatively fine sediment fractions because they tend to be more easily degraded and eroded.

In the western side of the Mira Channel increase the phyllosilicates (Fig. 2 e), OM (Fig. 3a), Al (Fig. 3b) and other elemental contents mostly associated with fine fraction (as suggested by the CA included in Fig. 4), which is indicative that this area is submitted to calmer hydrodynamical conditions. In this zone, the accumulation and degradation of organic matter may lead to a marked reduction of oxygen in surface sediment layers. Sulfur and Mo are two sensitive elements to redox conditions; the association of these elements with fine fraction and OM (CA of Fig. 4; subcluster 2.1) suggests that processes of organic matter degradation can lead to the retention of chemical elements in the sediments.

The CA sub-cluster 2.3 (Fig. 4) and the correlations presented in Appendix 2 indicate that calcite is significantly correlated with $\mathrm{Ca}$, Sr and dolomite contents. 
Tab. 1. Range of values of chemical elements in the analyzed samples.

\begin{tabular}{|c|c|c|c|}
\hline Element & Maximum & Minimum & Mean \\
\hline $\mathrm{Al}(\%)$ & 6.87 & 0.96 & 2.33 \\
\hline $\mathrm{Ba}(\mathrm{mg} / \mathrm{kg})$ & 373.0 & 117.0 & 219.8 \\
\hline $\mathrm{Be}(\mathrm{mg} / \mathrm{kg})$ & 5.00 & 0.30 & 1.44 \\
\hline $\mathrm{Ca}(\%)$ & 2.76 & 0.36 & 1.16 \\
\hline Ce (mg/kg) & 72.0 & 5.0 & 17.7 \\
\hline $\mathrm{Fe}(\%)$ & 3.15 & 0.07 & 0.53 \\
\hline $\mathrm{Hf}(\mathrm{mg} / \mathrm{kg})$ & 1.90 & 0.30 & 0.66 \\
\hline K (\%) & 3.06 & 0.93 & 1.70 \\
\hline $\mathrm{La}(\mathrm{mg} / \mathrm{kg})$ & 34.7 & 2.8 & 9.1 \\
\hline $\mathrm{Li}(\mathrm{mg} / \mathrm{kg})$ & 115.2 & 10.1 & 27.5 \\
\hline $\operatorname{Mg}(\%)$ & 0.96 & 0.03 & 0.16 \\
\hline Mn (mg/kg) & 415.0 & 14.0 & 114.9 \\
\hline Mo (mg/kg) & 1.98 & 0.03 & 0.22 \\
\hline $\mathrm{Na}(\%)$ & 3.03 & 0.28 & 0.74 \\
\hline $\mathrm{Nb}(\mathrm{mg} / \mathrm{kg})$ & 11.90 & 0.40 & 3.04 \\
\hline Rb (mg/kg) & 195.2 & 38.8 & 85.6 \\
\hline S (\%) & 1.10 & 0.03 & 0.13 \\
\hline Sc (mg/kg) & 8.00 & 0.03 & 1.48 \\
\hline $\mathrm{Sn}(\mathrm{mg} / \mathrm{kg})$ & 9.50 & 0.40 & 2.27 \\
\hline Sr (mg/kg) & 188.0 & 42.0 & 92.4 \\
\hline Ta (mg/kg) & 2.40 & 0.03 & 0.36 \\
\hline Th (mg/kg) & 16.9 & 1.2 & 3.7 \\
\hline $\mathrm{Ti}(\mathrm{mg} / \mathrm{kg})$ & 0.32 & 0.01 & 0.08 \\
\hline $\mathrm{U}(\mathrm{mg} / \mathrm{kg})$ & 3.10 & 0.40 & 1.01 \\
\hline $\mathrm{V}(\mathrm{mg} / \mathrm{kg})$ & 82.0 & 0.3 & 16.0 \\
\hline W (mg/kg) & 3.80 & 0.10 & 0.78 \\
\hline$Y(\mathrm{mg} / \mathrm{kg})$ & 16.3 & 0.8 & 3.0 \\
\hline $\mathrm{Zn}$ (mg/kg) & 134.0 & 2.0 & 20.4 \\
\hline $\mathrm{Zr}(\mathrm{mg} / \mathrm{kg})$ & 65.2 & 7.1 & 18.8 \\
\hline
\end{tabular}

In the study area, most part of the sedimentary carbonates are mainly related to biogenic remains (mollusks shells and tests of foraminifera). Most of the walls that delimit the engineering structures that keep the Ria de Aveiro mouth open are covered with mussel's colonies. Near the entrance of Mira Channel there are also mollusk crops. When these organisms die, the shells are probably transported and accumulated in some areas as the map of distribution of calcite revealed (Fig. 2 h). In zones of low depth, the evaporation of salt water should give rise to the chemical precipitation of carbonates, such as at the western zone of Mira Channel.

\subsection{Elemental Normalizers}

The characteristics of the terrigenous sediments deposited in a continental margin broadly reflect the prevailing climatic conditions, the geology of the continental source area and oceanographic processes (Herut and Sandler, 2006). The major input of sediment into the coastal marine and transitional environments is carried out by the rivers from the weathering of continental rocks (Herut and Sandler, 2006). Most of the analyzed elements in this work should be direct or indirectly related to sediment load transported by the littoral drift or by the rivers that discharge into the inner Aveiro Lagoon regions.

Theoretically, $\mathrm{Al}$ is a conservative major element, which has low anthropogenic input and is not significantly affected by, for instance, early diagenetic processes and strong redox effects (Dias and Prudêncio, 2008). Aluminium is the most commonly used normalizer because it represents aluminosilicates and finer sediments (Herut and Sandler, 2006). Thus, Al is generally used to account for granular variations of chemical elements in muddy sediments. These relationships are also observed in the study area as evidenced by the positive correlations of the $\mathrm{Al}$ concentrations with phyllosilicates, fine fraction and OM contents (Appendix 2). Organic matter is usually associated with fine-grained sediments and related to the increase of trace elements concentrations in Aveiro Lagoon (Martins et al., 2015). As mentioned, in this study, in addition to $\mathrm{Al}$, the efficiency of normalizers, such as $\mathrm{Li}$, $\mathrm{Fe}, \mathrm{Be}, \mathrm{Ce}, \mathrm{Fe}+\mathrm{Al}, \mathrm{Rb}$ and $\mathrm{Sc}$, is also tested. Lithium may be a better normalizer than $\mathrm{Al}$ in marine sediments enriched with clay minerals from eroded glacial material (Loring, 1990). Lithium and Sc make part of clay minerals and mica architecture, being good indicators of this kind of minerals, particularly in sediments containing Al-silicates in all size fractions (Dias and Prudêncio, 2008).

Scandium is usually associated with ferromagnesian minerals and biotite and shows preference for sulfate and carbonate phosphates (Shotyk et al., 2001). Fe has been satisfactorily used as a normalizer in several studies. However, Fe can be remobilized and replaced by pollutants in anoxic sediments. The use of $\mathrm{Fe}+\mathrm{Al}$ for normalization of the sediments does not yield a satisfactory estimation of the quantity of aluminosilicates, since the oxy-hydroxide fraction of $\mathrm{Fe}$ and $\mathrm{Al}$ often interferes with the siliceous fraction (Roulet et al., 2000). In few studies, Be, Rb and Ce have been used as normalizers (Herut and Sandler, 2006). However, due to analytical difficulties, their use has not been recommended for usual routines.

Despite the $\mathrm{Al}$ is one of the most commonly used normalizers in sedimentary studies (Summers et al., 1996; Covelli and Fontolan, 1997; Grant and Middleton, 1998; Aloupi and Angelidis, 2001; Yau and Gray, 2005; Ho et al., 2012), Grousset et al. (1995) did not consider it efficient, in a study performed in the Mediterranean Sea, due to its dependence of meteorological and hydrodynamical variations. In fact, they considered that Sc was the best normalizer because their concentrations in sediments were more similar to its regional levels in the rocks. Lee et al. 
(1994) emphasize that Sc is a good normalizing element, since it virtually has no industrial applications, is involatile and, thus, more accurately represents an entire crustal element.

The statistical results of this study suggest that the best normalizer as a lithogenic and conservative element is in fact the Sc. Considering that the Aveiro Lagoon entrance is a quite dynamical area characterized by hydrodynamical contrasts, which gives rise to heterogeneities in the sediment granulometry and composition and influence posdepositional processes, the element/Sc values seem to be largely independent of these parameters as evidenced by the PCA results.

\subsection{Possible sources of the sediments in the study area}

The elemental composition of sedimentary rocks may retain the record of their sources. The plots of Figure 5 evidence positive correlations of $\mathrm{Zr}$, $\mathrm{Hf}$ and $\mathrm{Th}$ concentrations with Ce, La, Y and Sc. Scandium and Y are conventionally taken together with the "rare earths" because of the similarity of many of their properties with the lanthanides and their rare occurrence in nature.

Scandium contents are generally low in sedimentary rocks; pure sandstone and limestone often contain $<2 \mathrm{mg}$ $\mathrm{kg}^{-1}$ whereas argillaceous rocks have higher contents, usually 10-30 $\mathrm{mg} \mathrm{kg}^{-1}$ (Kabata-Pendias and Pendias, 2001). The map of Sc subsoil distribution shows high values $\left(>13.5 \mathrm{mg} \mathrm{kg}^{-1}\right)$ in Variscan crystalline rocks of the Iberian Massif (Herut and Sandler, 2006). High Sc values can be correlated with crystalline rocks of intermediate to mafic or alkaline membership (Licht, 2001). Scandium is present in minute quantities in many minerals, notably monazite [(Ce, $\left.\mathrm{La}) \mathrm{PO}_{4}\right]$ which is frequently associated with granitic and gneissic rocks and derived sedimentary particles (Kabata-Pendias and Pendias, 2001).

Monazite frequently has relatively high thorium contents (Licht, 2001). Zirconium and Hf can be associated with heavy minerals (such as titanite, apatite, zircon, epidote, garnet and clay minerals) which may also control the REE distribution (Araújo et al., 2007). Thus, positive correlations of Ce, La, Y and Sc with Zr, Hf and Th should indicate a common source of these chemical elements, that is, the one with Variscan granitic and gneissic rocks. Hafnium belongs to the (Ti) Zr group and may occur in association with some oxide and silicate minerals such as zircon (Cox, 1995).

The high positive correlations among $\mathrm{Zr}$ and $\mathrm{Hf}$ and the REE contents (Appendix 2) suggest that the mineral zircon is mainly responsible for holding these elements. As noticed by Cascalho and Carvalho (1993), the zircon minerals $\left(\mathrm{ZrSiO}_{4}\right)$ are concentrated in coarser-grained sediments and are widely spread along the NW Portuguese Continental Shelf. Zircon (also garnet and apatite) is a heavy mineral with important REE abundances (Araújo et al., 2007), which is a common accessory constituent of most granite, felsic igneous rocks and metasedimentary rocks observed in the region.

On the other hand, all the element/Sc ratios are joined in the PCA of Fig. 6, in a group (II) independent of the sediment grain size parameters. The distribution pattern of Ce/Sc (Fig. 3c) may give the idea of the general distribution of other element/Sc ratios. The heterogeneity of the distribution of $\mathrm{Ce} / \mathrm{Sc}$ values and all other element/Sc ratios indicate that the materials deposited in the study area should result of a mixture of sedimentary sources. However, the map of distribution of the stations' groups (Fig. 8) identified by the Q-mode CA (Fig. 7) allowed to distinguish some different patterns in the sediments composition of the study area.

Table 2 shows very high values for several element/Sc ratios (such as $\mathrm{Al} / \mathrm{Sc}, \mathrm{Ce} / \mathrm{Sc}, \mathrm{La} / \mathrm{Sc}, \mathrm{Li} / \mathrm{Sc}, \mathrm{Rb} / \mathrm{Sc}, \mathrm{Th} / \mathrm{Sc}$, $\mathrm{V} / \mathrm{Sc}$ and $\mathrm{Zr} / \mathrm{Sc}$ ) in the stations of Cluster 5 (Fig. 7). So, this group, composed of only three stations, was considered an outlier. Therefore, only the characteristics of the stations of the Clusters I-IV (Fig. 7) are discussed in the next item.

The stations of the Cluster II (Fig. 7 and Table 2) are characterized by the highest $\mathrm{K} / \mathrm{U}$ values, and the lowest $\mathrm{Ce} / \mathrm{Sc}$ and $\mathrm{Th} / \mathrm{Sc}$ values. The largest number of stations of this group are located at the entrance of the lagoon inlet. This number decreases toward the inland along the S. Jacinto and Mira Channels. This pattern suggests the entry, through the Aveiro Lagoon mouth, of materials sourced by K-rich granitic rocks, which dominate the lithology of the Douro River hydrographical basin (Ferreira et al., 2010), located at north of the study area.

The stations of Cluster III (Fig. 7 and Table 2) are those that are located at the lowest depths and are characterized by lower values of SMGS, quartz, K-feldspars and by higher values of fines, sorting, OM, plagioclase, calcite, dolomite, phyllosilicates, Ce/Ce*, $\mathrm{La} / \mathrm{La}^{*}, \mathrm{Y} / \mathrm{Y}^{*}, \mathrm{Sc} / \mathrm{Sc}^{*}$ and $\mathrm{Th} / \mathrm{U}$ values. Minerals, such as monazite and zircon, which are strongly resistant to erosion, may be carriers of Ce, La, Y, Sc and Th. Thorium concentrations are generally higher in granitic than mafic igneous rocks forming minerals such as biotite (Licht, 2001). In sediments, Th is strongly adsorbed by clay minerals and can trace the contribution of those materials.

Black shale may have higher Th concentrations, but never as high as the $U$ content, because of the much stronger affinity of $U$ for organic material and the greater mobility of oxidized $\mathrm{UO}_{2}^{2+}$ in solution (Kabata-Pendias and Pendias, 2001). The largest number of stations in Group III are located in areas relatively protected from the action of the most active currents, such as on the west side of Mira Channel and near the South-Jetty. The stations of Group III correspond to depositional sites where fine-grained materials supplied essentially from granitites erosion are being accumulated (Fig. 8). 


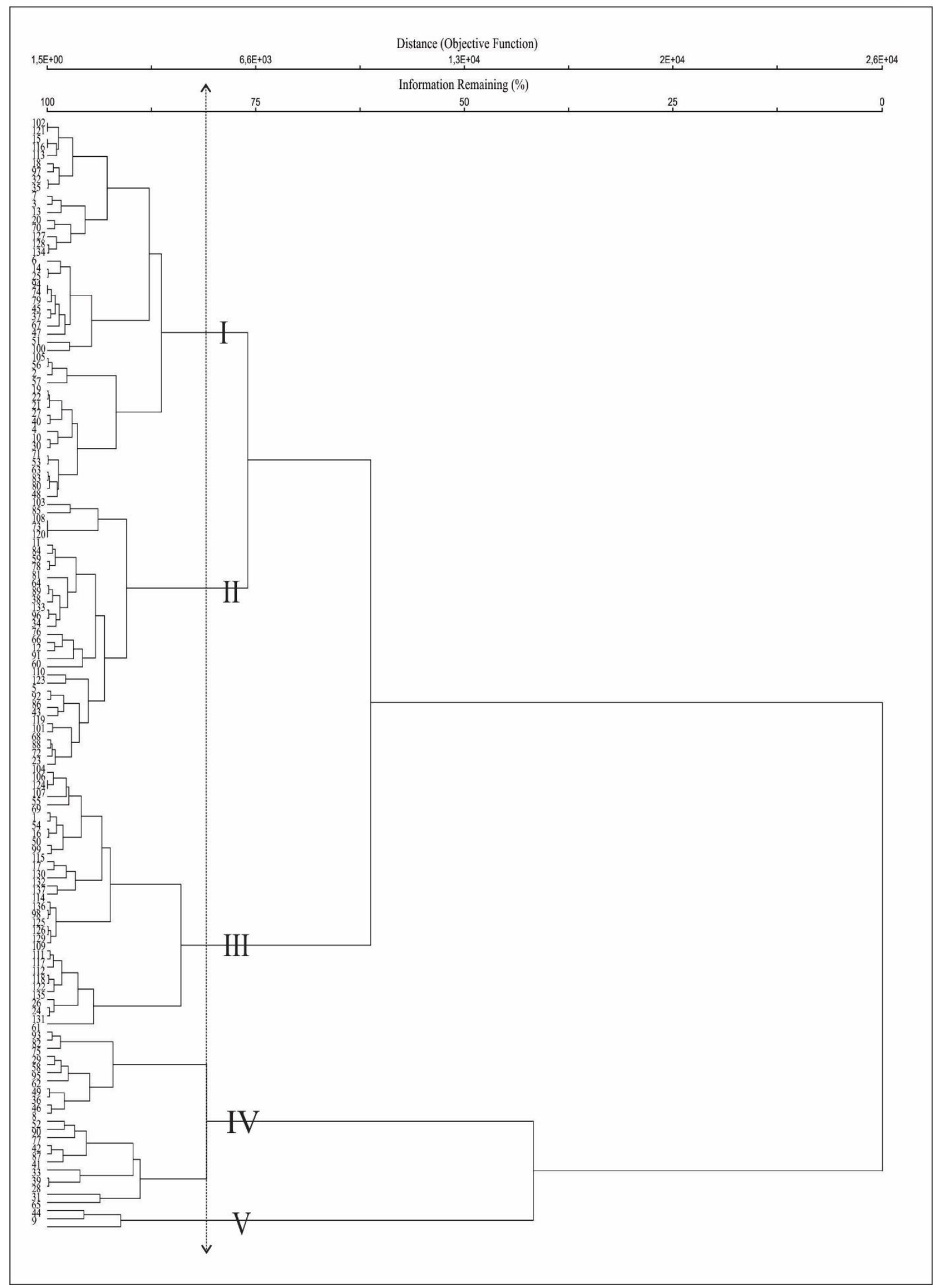

Fig. 7. Results of Q-mode cluster analysis based on selected variables, such as Ce/Sc, $\mathrm{La} / \mathrm{Sc}, \mathrm{Th} / \mathrm{Sc}, \mathrm{Al} / \mathrm{Sc}, \mathrm{Zr} / \mathrm{Sc}, \mathrm{Rb} / \mathrm{Sc}, \mathrm{La} / \mathrm{La}$, $\mathrm{Ce} / \mathrm{Ce}^{*}, \mathrm{Y} / \mathrm{Y}^{*}, \mathrm{Sc} / \mathrm{Sc} c^{*} \mathrm{Nb} / \mathrm{Ta}, \mathrm{La} / \mathrm{Ta}, \mathrm{Th} / \mathrm{U}, \mathrm{K} / \mathrm{U}$ and the other analyzed variables (depth, fine fraction, SMGS, sorting, quartz, Kfeldspars, plagioclase, calcite, dolomite, phyllosilicates and organic matter values). The asterisks $(*)$ indicate the normalized elements by the respective upper continental crust composition (according to Rudnick and Gao, 2003). 
Tab. 2. Mean values of the variables (the same used in the PCA of Figure 7) for the groups of stations identified by the CA. The highest values are shaded and the lower values are signed by the blue letter for the Clusters I-IV, since the Cluster V was considered an outlier (see the text). Legend: SMGS - sediment mean grain size; Qtz - quartz; <63 $\mu \mathrm{m}$ - fine fraction; TOC - total organic carbon; Sort sorting; Phyl - phyllosilicates; Calc - calcite; Dol - dolomite; K-Feld - K-feldspars; Plag - plagioclase. The asterisks (*) indicate the normalized elements by the respective upper continental crust composition (according to Rudnick and Gao, 2003).

\begin{tabular}{|l|c|c|c|c|c|}
\hline Variables & Cluster I & Cluster II & Cluster III & Cluster IV & Cluster V \\
\hline Depth & 15.6 & 14.5 & 5.7 & 21.2 & 5.0 \\
\hline$<63 \mu \mathrm{m}$ & 0.4 & 1.5 & 21.1 & 0.2 & 0.3 \\
\hline $\mathrm{SMGS}$ & 536 & 353 & 121 & 1741 & 1190 \\
\hline $\mathrm{Sort}$ & 1.6 & 1.8 & 2.3 & 1.5 & 1.8 \\
\hline $\mathrm{TOC}$ & 0.45 & 0.66 & 2.62 & 0.34 & 0.54 \\
\hline $\mathrm{Qtz}$ & 68.9 & 61.7 & 48.0 & 65.7 & 66.2 \\
\hline $\mathrm{K}-\mathrm{Feld}$ & 12.5 & 12.3 & 10.8 & 14.3 & 16.4 \\
\hline $\mathrm{Plag}$ & 4.6 & 7.8 & 12.6 & 4.7 & 4.4 \\
\hline $\mathrm{Calc}$ & 1.9 & 2.2 & 2.6 & 1.8 & 1.6 \\
\hline $\mathrm{Dol}$ & 0.8 & 1.2 & 2.1 & 1.2 & 1.1 \\
\hline $\mathrm{Phyl}$ & 6.2 & 9.9 & 16.0 & 6.9 & 5.1 \\
\hline $\mathrm{Al} / \mathrm{Sc}$ & 4.5 & 1.9 & 1.4 & 3.1 & $\underline{46.1}$ \\
\hline $\mathrm{Ce} / \mathrm{Sc}$ & 24.8 & 11.2 & 12.8 & 19.1 & $\underline{244.4}$ \\
\hline $\mathrm{La} / \mathrm{Sc}$ & 12.8 & 5.7 & 6.4 & 9.6 & $\underline{130.0}$ \\
\hline $\mathrm{Li} / \mathrm{Sc}$ & 47.5 & 17.1 & 15.8 & 36.5 & $\underline{558.9}$ \\
\hline $\mathrm{Rb} / \mathrm{Sc}$ & 186.4 & 78.3 & 46.6 & 136.2 & $\underline{2015.6}$ \\
\hline $\mathrm{Th} / \mathrm{Sc}$ & 5.6 & 2.4 & 2.7 & 4.4 & $\underline{55.6}$ \\
\hline $\mathrm{V} / \mathrm{Sc}$ & 3.4 & 3.3 & 3.2 & 3.8 & $\underline{5.6}$ \\
\hline $\mathrm{Zr} / \mathrm{Sc}$ & 38.7 & 13.2 & 10.4 & 30.2 & $\underline{361.1}$ \\
\hline $\mathrm{Ce} / \mathrm{Ce} *$ & 0.001 & 0.003 & 0.008 & 0.002 & 0.001 \\
\hline $\mathrm{La} / \mathrm{La} *$ & 0.124 & 0.222 & 0.701 & 0.168 & 0.126 \\
\hline $\mathrm{Y} / \mathrm{Y} *$ & 0.069 & 0.122 & 0.311 & 0.093 & 0.059 \\
\hline $\mathrm{Sc} / \mathrm{Sc} *$ & 0.021 & 0.089 & 0.295 & 0.051 & 0.002 \\
\hline $\mathrm{Nb} / \mathrm{Ta}$ & 13.7 & 13.0 & 8.3 & 11.1 & $\underline{13.4}$ \\
\hline $\mathrm{Th} / \mathrm{U}$ & 2.9 & 3.4 & 4.5 & 2.6 & 2.5 \\
\hline $\mathrm{K} / \mathrm{U}$ & 2.2 & 2.5 & 1.5 & 1.7 & 1.9 \\
\hline $\mathrm{La} / \mathrm{Ta}$ & 67.5 & 40.6 & 24.2 & 46.8 & $\underline{64.7}$ \\
\hline & & & & & \\
\hline
\end{tabular}

The stations of Cluster I (CA of Fig. 7) are characterized by higher quartz, $\mathrm{Al} / \mathrm{Sc}, \mathrm{Ce} / \mathrm{Sc}, \mathrm{La} / \mathrm{Sc}, \mathrm{Li} / \mathrm{Sc}, \mathrm{Rb} / \mathrm{Sc}$, $\mathrm{Th} / \mathrm{Sc}, \mathrm{Zr} / \mathrm{Sc}, \mathrm{La} / \mathrm{Ta}$ and $\mathrm{Nb} / \mathrm{Ta}$ values, associated with relatively coarse sediments (medium sands). The stations of Group I (CA of Fig. 7) occur mainly along the navigable routs of the Aveiro Lagoon inlet, S. Jacinto and Mira channels (Fig. 8). These stations have more reworked sediments, as suggested by the highest percentages of quartz and reduced contents of feldspars. They are also characterized by higher values of, for instance, $\mathrm{Zr} / \mathrm{Sc}$, $\mathrm{Ce} / \mathrm{Sc}, \mathrm{La} / \mathrm{Sc}, \mathrm{Th} / \mathrm{Sc}$ and $\mathrm{La} / \mathrm{Ta}$, which may be related to zircon and monazite.

The presence of quartz, and possibly zircon and monazite, in the sediments of Aveiro Lagoon entrance, which is affected by strong flood and ebb currents on navigable routes (Vaz et al., 2005), is probably due to the high resistance of these minerals to erosion.

\section{Conclusion}

The results of this work have indicated that the best normalizer at Aveiro Lagoon entrance, which is complex from the point of view of sedimentary dynamics, is Sc. Mapping clusters established by the Q-mode CA and, considering the mean values of the analyzed variables (including the element/Sc ratios) for the different stations, it was possible to distinguish different sediment sources. Sediments from the granite erosion, which should be supplied mostly by the Douro River Basin, enter through the lagoon inlet and are the most important components of the 
sediments at the lagoon entrance. The sediments constantly remobilized within the lagoon entrance are also essentially derived from granites. The sediments from the SchistGreywacke Complex seem to be mostly supplied by the rivers that discharge into the lagoon; they are transported by tidal currents and are transitorily deposited in the lagoon mouth; and they may leave the lagoon and be scattered across the continental shelf.

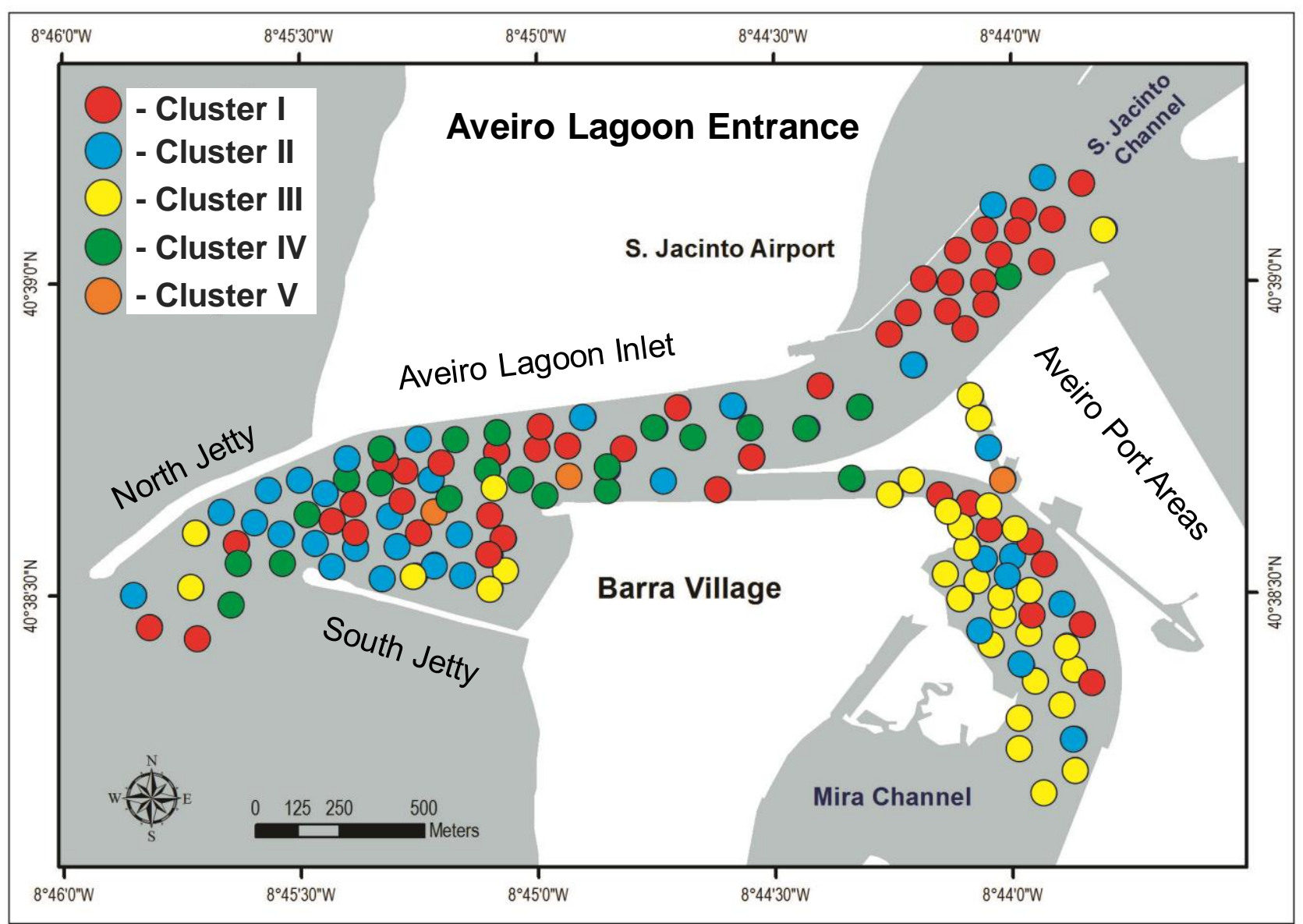

Fig. 7. The map of distribution of the stations' clusters identified by Q-mode Cluster Analysis included in Fig. 7.

\section{Acknowledgments}

The authors would like to thank the three anonymous reviewers and the Editor who helped to improve this work. This work was financed by Fundação para a Ciência e a Tecnologia (FCT, Portugal) through the strategic project UID/GEO/04035/2013 and the EMERA project - Morfodynamic Study of Ria de Aveiro Inlet. The first author would like to thank Conselho Nacional de Desenvolvimento Científico e Tecnológico, CnPQ, Brazil, by the research grant (reference number: 301588/2016-3).

Appendices 1-4 are attached as supplementary materials (SM1-SM4) in:

http://www.e-publicacoes.uerj.br/index.php/jse/article/view/34815

\section{References}

Abecassis, C.K., 1954. The history of a tidal lagoon inlet and its improvement (The case of Aveiro, Portugal). In: Johnson, J.W.
(Ed.), Berkley, California: Council on Wave Research, The Engineering Foundation, Proceedings of the Fifth Conference on Coastal Engineering, Grenoble, France, September 1954, pp. 329-363.

Abrantes, I., Rocha, F., Vidinha, J., Dias, J.A., 2005. Influence of Aveiro Lagoon heavy metal contents in the adjacent continental shelf (Portugal). Ciencias Marinas 31(1B), 149-160.

Aloupi, M., Angelidis, M.O., 2001. Geochemistry of natural and anthropogenic metals in the coastal sediments of the island of Lesvos, Aegean Sea. Environmental Pollution 113, 211-219. https://doi.org/10.1016/S0269-7491(00)00173-1

Amaral, I., 1968. As inundações de 25-26 de novembro de 1967 na região de Lisboa. Finisterra 3, 79-84.

Araújo, M.F., Corredeira, C., Gouveia, A., 2007. Distribution of the rare earth elements in sediments of the Northwestern Iberian Continental Shelf. Journal of Radioanalytical and Nuclear Chemistry 271 (2), 255-260.

Azpurua, M.A., Ramos, K.D., 2010. A comparison of spatial interpolation methods for estimation of average 
electromagnetic field magnitude. Progress in Electromagnetics Research 14, 135-145. https://doi.org//10.2528/ PIERM10083103

Barbier, E.B., Koch, E.W., Silliman, B.R., Hacker, S.D., Wolanski, E., Primavera, J., Granek, E.F., Polasky, S., Aswani, S., Cramer, L.A., Stoms, D.M., Kennedy, C.J., Bael, D., Kappel, C.V., Perillo, G.M.E., Reed, D.J., 2008. Coastal ecosystem-based management with nonlinear ecological functions and values. Science, 319 (5861), 321-323

Barbosa, B.P., 1981. Notícia explicativa da folha 16-C (Vagos) da Carta Geológica de Portugal na escala 1:50000 [Explanatory note of the sheet 16-C (Vagos) of the Geological Map of Portugal, scale 1:50000]. Serviços Geológicos de Portugal.

Bastos, M.R., Alveirinho Dias, J., Dias, A.C., Pereira, S.D., Oliveira, N.V., Rodrigues, M.A., 2012. Sustainable coastal zones? A matter of "sense and sensibility: Comparative analysis between Aveiro Lagoon (Portugal) and Sepetiba Bay (Brazil). Management of Environmental Quality: An International Journal, 23 (4), 383-399. https://doi.org/10.1108/ 14777831211232218

Blott, S.J., Pye, K., 2001. GRADISTAT: a grain size distribution and statistics package for the analysis of unconsolidated sediments. Earth Surface Process Landforms 26, 1237-1248. https://doi.org/10.1002/esp.261

Borges, P.A., Franke, J., Anunciação, Y.M.T., Weiss, H., Bernhofer, C., 2016. Comparison of spatial interpolation methods for the estimation of precipitation distribution in Distrito Federal, Brazil. Theoretical and Applied Climatology 123 (1), 335-348. https://doi.org/10.1007/s00704-014-1359-9

Burningham, H., French, J., 2017. Understanding coastal change using shoreline trend analysis supported by cluster-based segmentation. Geomorphology 282, 131-149. https://doi.org/10.1016/j.geomorph.2016.12.029

Cascalho, J.P., Carvalho, A.M.G., 1993. Proveniência dos minerais pesados da plataforma continental portuguesa a norte do paralelo de Espinho. Gaia 6, 10-25.

Chai, H., Cheng, W., Zhou, C., Chen, X., Ma, X., Zhao, S., 2011. Analysis and comparison of spatial interpolation methods for temperature data in Xinjiang Uygur Autonomous Region, China. Journal of Nature and Science 3 (12), 999-1010.

Chang, Y., Chu, K-W, Chuang, L. Z-H, 2018. Sustainable coastal zone planning based on historical coastline changes: A model from case study in Tainan, Taiwan. Landscape and Urban Planning 174, 24-32.

Chester, R., 1990. Marine Chemistry. Cambridge University Press, 382 pp.

Clark, R., 2001. Marine pollution, Oxford University Press.

Covelli, S., Fontolan, G., 1997. Application of a normalization procedure in determining regional geochemical baselines, Gulf of Trieste, Italy. Environmental Geology 30 (1/2), 34-45.

Cox, P.A., 1995. The Elements on Earth, Oxford University Press, United States, p. 287.

Cunha, S.R., 1930. Relance da história económica de Aveiro: soluções para o seu problema maritimo. Aveiro, Imprensa Universal.

Dias, J.M., Lopes, J.F., Dekeyser, I., 2001. Lagrangian transport of particles in Ria de Aveiro lagoon, Portugal. Physics and Chemistry of the Earth, Part B, 26 (9), 721-727.
https://doi.org/10.1016/S1464-1909(01)00076-4.

Dias, J.M., Lopes, J.F., Dekeyser, I., 2000. Tidal propagation in Ria de Aveiro Lagoon, Portugal. Physics and Chemistry of the Earth (B) 25 (4), 369-374.

Dias, J.M., Lopes, J.F., Dekeyser, I., 1999. Hydrological characterization of Ria de Aveiro lagoon, Portugal, in early summer. Oceanologica Acta 22, 473-485.

Dias, J.M.A., 1987. Dinâmica sedimentar e evolução recente da Plataforma Continental Portuguesa Setentrional. PhD thesis, Universidade de Lisboa, $384 \mathrm{pp}$.

Dias, M.I., Prudêncio, M.I., 2008. On the importance of using scandium to normalize geochemical data preceding multivariate analyses applied to archaeometric pottery studies. Microchemical Journal 88, 136-141. https://doi.org/10.1016/ j.microc.2007.11.009

Ducrotoy, J.P., Elliott, M., De Jonge, V., 2000. The North Sea: an evaluation. Marine Pollution Bulletin 41, 5-23.

Dutton, C., Anisfeld, S.C., Ernstberger, H., 2013. A novel sediment fingerprinting method using filtration: application to the Mara River, East Africa. Journal of Soils and Sediments 13, 1708-1723. https://doi.org/10.1007/s11368-013-0725-z

Ferreira, A.M.P.J., 2000. Dados geoquímicos de base de sedimentos fluviais de amostragem de baixa densidade de Portugal Continental. Estudo de factores de variação regional. PhD thesis, LNEG, Laboratório Nacional de Engenharia e Geologia I.P., Portugal. http://hdl.handle.net/10400.9/542

Ferreira, C., Gomes, A., Antón, L., 2010. Knickpoints na bacia hidrográfica do Douro: análise da sua distribuição e implicações estruturais. VI Seminário Latino-Americano de Geografia Física. Coimbra.

Fiúza, A., Macedo, A.M., Guerreiro, M., 1982. Climatological space and time variation of the Portuguese coastal upwelling. Oceanologica Acta 5, 31-40.

Folk, R.L., Ward, W.C., 1957. Brazos River bar: a study in the significance of grain size parameters. Journal of Sedimentary Petrology 27 (1), 3-26.

Frouin, R., Fiúza, A.F.G., Ambar, I., Boyd, T.J., 1990. Observations of a poleward surface current off the coast of Portugal and Spain during winter. Journal of Geophysical Research 95 (C1), 679-691.

Girão, A.A., 1941. Geografia de Portugal. Portucalense Editora, Porto, 479 p.

Godschalk, D.R., 2009. Coastal Zone Management. In: Encyclopedia of Ocean Sciences (Second Edition).

Goovaerts, P., 2000. Geostatistical approaches for incorporating elevation into the spatial interpolation of rainfall. Journal of Hydrology 228, 113-129. https://doi.org/10.1016/S00221694(00)00144-X

Grant, A., Briggs, A.D., 2002. Toxicity of sediments from around a North Sea oil platform: are metals or hydrocarbons responsible for ecological impacts? Marine Environmental Research 53, 95-116.

Grant, A., Middleton, R., 1998. Contaminants in sediments: using robust regression for grain-size normalization. Estuaries 21 (2), 197-203.

Grousset, F.E., Quetel, C.R., Thomas, B., Donard, O.F.X., Lambert, C.E., Quillard, F., Monaco, A., 1995. Anthropogenic vs. lithogenic origins of trace elements (As, $\mathrm{Cd}, \mathrm{Pb}, \mathrm{Rb}, \mathrm{Sb}, \mathrm{Sc}, \mathrm{Sn}$, 
$\mathrm{Zn})$ in water column particles: northwestern Mediterranean Sea. Marine Chemistry 48, 291-310.

Haskin, M.A., Haskin, L.A., 1966. Rare Earths in European Shales: A Redetermination. Science New Series, 154 (3748), 507-509.

Haynes, R., Barton, E.D., 1990. A poleward flow along the Atlantic coast of the Iberian Peninsula, Journal of Geophysical Research 95 (C7), 11425-11441.

Herut, B., Sandler, A., 2006. Normalization methods for pollutants in marine sediments: review and recommendations for the Mediterranean, IOLR Report H18/2006 Submitted to UNEP/MAP.

Ho, H.H., Swennen, R., Cappuyns, V., Vassilieva, E., Tran, T.V., 2012. Necessity of normalization to aluminum to assess the contamination by heavy metals and arsenic in sediments near Haiphong Harbor, Vietnam. Journal of Asian Earth Sciences 56, 229-239.

Huthnance, J.M., Van Aken, H.M., White, M., Barton, E.D., Le Cann, B., Coelho, E.F., Fanjul, E.A., Miller, P.I., Vitorino, J., 2002. Ocean margin exchange- water flux estimates. Journal of Marine System 32, 107-137. https://doi.org/10.1016/S09247963(02)00034-9.

Isaaks, E.H., Srivastava, R.M., 1989. An Introduction to Applied Geostatistics. Oxford University Press, New York, 561 p.

Kabata-Pendias, A., Pendias, H., 2001. Trace elements in soils and plants. 3rd ed., 403 p.

Karageorgis, A.P., Katsanevakis, S., Kaberi, H., 2009. Use of Enrichment Factors for the Assessment of Heavy Metal Contamination in the sediments of Koumoundourou Lake, Greece. Water Air Soil Pollution 204, 243. https://doi.org/10.1007/s11270-009-0041-9

Keblouti, M., Ouerdachi, L., Boutaghanea, H., 2012. Spatial interpolation of annual precipitation in Annaba-Algeria Comparison and evaluation of methods. Energy Procedia 18, $468-475$.

Lee, D., Garland, J., Fox, A., 1994. Atmospheric concentrations of trace elements in urban areas of the United Kingdom. Atmospheric Environment 28, 2691-2713.

Licht, O.A.B., 2001. A geoquímica multielementar na gestão ambiental: identificação e caracterização de províncias geoquímicas naturais, alterações antrópicas da paisagem, areas favoráveis à prospecção mineral e regiões de risco para a saúde no estado do Paraná, Brasil. UFPR. PhD thesis, Curitiba, 238 p.

Lillebo, A.I., Queiroga, H., Dias, J.M., Alves, F.L., Cleary, D.F.R., 2011. Ria de Aveiro: Uma visão dos processos ambientais, ecológicos e socioeconómicos. Actas das Jornadas da Ria de Aveiro 2011.

Lira, C.P., Silva, A.N., Taborda, R., Andrade, C.F., 2016. Coastline evolution of Portuguese low-lying sandy coast in the last 50 years: an integrated approach. Earth System Science Data 8, 265-278. https://doi.org/10.5194/essd-8-265-2016

Lopes, C. L., Dias, J. M., 2015. Tidal dynamics in a changing lagoon Flooding or not flooding the marginal regions. Estuarine, Coastal and Shelf Science, 167, Part A, 14-24. https://doi.org//10.1016/j.ecss.2015.05.043.

Lopes, C. L., Dias, J. M., Dekeyser, I., 2006. Numerical modelling of cohesive sediments transport in the Ria de Aveiro lagoon, Portugal. Journal of Hydrology 319, 176-198. https://doi.org//10.1016/j.jhydrol.2005.07.019

Loring, D.H., 1990. Lithium - a new approach for the granulometric normalization of trace metal data. Marine Chemistry 29, 155-168. https://doi.org/10.1016/03044203(90)90011-Z

Martínez, M.L., Silva, R., Lithgow, D., Mendoza, E., Flores, P., Martínez, R., Cruz, C., 2017. Human impact on coastal resilience along the coast of Veracruz, Mexico. In: Martinez, M.L., Taramelli, A., Silva, R. (eds.), Coastal Resilience: Exploring the Many Challenges from Different Viewpoints. Journal of Coastal Research, Special Issue $N^{0} 77$, pp. 143-153. https://doi.org/10.2112/SI77-015.1

Martins, F., 1947. A configuração do litoral Portugues no último quartel do século XIV - Apostila a um mapa. Biblos, XXII (1), 163-197.

Martins, M.V.A., Laut, L.L.M., Duleba, W., Zaaboub, N., Aleya, L., Terroso, D.L., Sequeira, C., Pena, A., Rodrigues, M.A., Rocha, F., 2017. Sediment quality and possible uses of dredged materials: the Ria de Aveiro lagoon mouth area (Portugal). Journal of Sedimentary Environments 2 (2), 149-166.

Martins, M.V.A., Dardon, U., Frontalini, F., Silva, E.F., Zaaboub, N., Jones, C.M., Pereira, E., Bergamaschi, S., Dias, J.A., Rocha, F., 2016. Rare Earth Elements used as fingerprints of differentiated sediment sources in the Ria de Aveiro (Portugal). Journal of Sedimentary Environments 1 (1), 17-42. https:/ / doi.org/10.12957/ jse.2016.21444

Martins, V.A., Silva, F., Lazaro, L.M.L., Frontalini, F., Clemente, I.M., Miranda, P., Figueira, R., Sousa, S.H.M., Dias, J.M.A., 2015. Response of benthic foraminifera to organic matter quantity and quality and bioavailable concentrations of metals in Aveiro Lagoon (Portugal). PLoS ONE 10 (2): e0118077. https://doi.org/10.1371/journal.pone.0118077

Martins, M.V., Dubert, J., Jouanneau, J.-M., Weber, O., Silva, E.F., Patinha, C., Alveirinho Dias, J.M., Rocha, F., 2007. A multiproxy approach of the Holocene evolution of shelf-slope circulation on the NW Iberian Continental Shelf. Marine Geology 239, 1-18.

Mazé, J.P., Arhan, M., Mercier, H., 1997. Volume budget of the eastern boundary layer off Iberian Peninsula. Deep Sea Research Part I, Oceanographic Research Papers, 44, 1543-1574. https://doi.org/10.1016/S0967-0637(97)00038-1

McLennan, S.M., Murray, R.W., 1999. Geochemistry of Sediments. In: Marshall, C.P. and Fairbridge, R.W. (eds.), Encyclopedia of Geochemistry, Dordrecht: Kluwer Academic.

Naoum, S., Tsanis, I.K., 2004. Ranking spatial interpolation techniques using a GIS-based DSS. Global Nest 6, 1-20.

Neves, F.F., 1935. Breve história da Barra de Aveiro. Arquivo do Distrito de Aveiro 1, 219-238.

Oliver, H., Lotte, A.F., Lemcke, G., 2001. Loss on ignition as a method for estimating organic and carbonate content in sediments: reproducibility and comparability of results. Journal of Paleolimnology 25, 101-110. https://doi.org/10.1023/ A:1008119611481

Pereira, M.E., Duarte, A.C., Millward, G.E., Abreu, S.N., Vale, C., 1998. An estimation of industrial mercury stored in sediments of a confined area of the Lagoon of Aveiro (Portugal). Water Science and Technology 37 (6-7), 125-130.

Pérez-Estaún, A., Bea, F., Bastida, F., Marcos, A., MartínezCatalán, J.R., Martínez Poyatos, D., Arenas, R., Díaz García, 
F., Azor, A., Simancas, J. F., González Lodeiro, F., 2004. Macizo Ibérico. In: Vera, J.A. (Ed.), Geologia de España, Sociedad Geológica de España, Instituto Geológico y Minero de España, pp. 221-230.

Pethick, J.S., Crooks, S., 2000. Development of a coastal vulnerability index: a geomorphological perspective. Environmental Conservation 27, 359-367.

Plecha, S., Silva, P.A., Oliveira A., Dias, J. M., 2012. Establishing the wave climate influence on the morphodynamics of a coastal lagoon inlet. Ocean Dynamics 62 (5), 799-814. http://dx.doi.org/10.1007/s10236-012-0530-z

Plecha, S., Silva, P.A., Vaz, N., Bertin, X., Oliveira, A., Fortunato, A.B., Dias, J.M., 2010. Sensitivity analysis of a morphodynamic modeling system applied to a coastal lagoon inlet. Ocean Dynamics 60, 275-284.

Ribeiro, A., Antunes, M.T., Ferreira, M.P., Rocha, R.B., Soares, A.F., Zbyszewski, G., Almeida, F.M., Carvalho, D., Monteiro, J.H. 1979. Introduction à la géologie generale du Portugal. Serviços Geológicos de Portugal, Lisboa, pp. 15 - 17.

Rocha, F., Silva, E., Vidinha, C. B. J., Patinha, C., 2005. Chemical and mineralogical characterization of the sediments from the Mira, Illhavo and Ovar channels of Aveiro Lagoon (Portugal). Ciencias Marinas 31(1B), 253-263.

Rocha, F., Gomes, C., 1992. Morpho-climatic evolution of the Aveiro littoral region (NW of Portugal) during Tertiary and Quaternary. Conference Proceedings edition: Proceedings of the International Coastal Congress, ICC-Kiel '92, pp. 157-166.

Rodrigues, A., Dias, J.M.A., 1989. Evolução pós-glaciária da Plataforma Continental a Norte do Cabo Mondego. Anais do Instituto Hidrográfico 10, 39-50. Lisboa.

Rodrigues, M., Queiroga, H., Oliveira, A., Brotas, V., Manso, M.D., 2016. Climatic and anthropogenic factors driving water quality variability in a shallow coastal lagoon (Aveiro lagoon, Portugal): 1985-2010 data analysis. AIMS Environmental Science, 3 (4), 673-696. https://doi.org/10.3934/ environsci.2016.4.673

Roulet, M., Lueotte, M., Canuel, R., Farella, N., Courcelles, M., Guimaraes, J., Mergler, D., Amorim, M., 2000. Increase in mercury contamination recorded in lacustrine sediments following deforestation in the central Amazon. Chemical Geology 165, 243-261.

Rudnick, R.L., Gao, S., 2003. Composition of the Continental Crust. In: Rudnick, R.L., Holland, H.D., Turekian, K. K., Treatise on Geochemistry, pp. 659. Elsevier. https://doi.org/ 10.1016/ B0-08-043751-6/03016-4

Sakan, S.M., Đorđević, D.S., Trifunović, S.S., 2011. Geochemical and statistical methods in the evaluation of trace elements contamination: an Application on Canal Sediments. Polish Journal of Environmental Studies 20 (1), 187-199.

Salomons, W., Stigliani, W., 1995. Biogeodynamics of pollutants in soils and sediments. Berlin, Spring-Verlag, pp. 352.
Schiff, K.C., Weisberg, S.B., 1999. Iron as a reference element for determining trace metal enrichment in Southern California coastal shelf sediments. Marine Environment Research 48, 161-176.

Shotyk, W., Weiss, D., Kramers, J.D., Frei, R., Cheburkin, A.K., Gloor, M., Reese, S. 2001. Geochemistry of the peat bog at Etang de la Gruère, Jura Mountains, Switzerland and its record of atmospheric $\mathrm{Pb}$ and lithogenic trace elements ( $\mathrm{Sc}, \mathrm{Ti}, \mathrm{Y}, \mathrm{Zr}$, Hf and REE) since $12,370{ }^{14} \mathrm{C}$ yr BP. Geochimica et Cosmochimica Acta 65, 2337-2360.

Silva, J., 1992. Dependence of upwelling related circulation on wind forcing and stratification over the Portuguese northern shelf. ICES Hyd. Comm. CM 1992/C, 17 pp.

Stronkhorst, J., Huisman, B., Giardino, A., Santinelli, G., Santos, F.D., 2018. Sand nourishment strategies to mitigate coastal erosion and sea level rise at the coasts of Holland (The Netherlands) and Aveiro (Portugal) in the $21^{\text {st }}$ century. Ocean and Coastal Management, 156, 266-276. https://doi.org/10.1016/j.ocecoaman.2017.11.017

Summers, J.K., Wade, T.L., Engle, V.D., Malaeb, Z.A., 1996. Normalization of metal concentrations in estuarine sediments from the Gulf of Mexico. Estuaries 19 (3), 581-594.

Teixeira, C., 1981. Geologia de Portugal. Vol I - Precâmbrico, Paleozóico. Fundação Calouste Gulbenkian, Lisboa, 629 pp.

Terzopoulos, D., 1988. The computation of visible-surface representations. IEEE Transactions on Pattern Analysis and Machine Intelligence 10(4), 417-438. https://doi.org/ $10.1109 / 34.3908$

USEPA, 1996. SW-846 Method 3052: microwave assisted acid digestion of siliceous and organically based matrices. U.S. Gov. Print Office, Washington.

USEPA, 2007. SW-846 Method 6020A: inductively coupled plasma-mass spectrometry. U.S. Gov. Print Office, Washington.

Vaz, N., Dias, J.M., Leitão, P., Martins, I., 2005. Horizontal patterns of water temperature and salinity in an estuarine tidal channel: Ria de Aveiro. Ocean Dynamics 55, 416-429. https://doi.org/10.1007/s10236-005-0015-4

Wooster, W.S., Bakun, A., Mclain, D.R., 1976. The seasonal upwelling cycle along the eastern boundary of the North Atlantic. Journal of Marine Research 34(2), 131-141.

Yau, H., Gray, N.F., 2005. Riverine sediment metal concentrations of the Avoca-Avonmore catchment, South-east Ireland: a baseline assessment. Biology and Environment: Proceedings of the Royal Irish Academy 105b (2), 95-106.

Yizhaq, H., Katra, I., Kok, J.F., Isenberg, O. 2012. Transverse instability of megaripples. Geology 40 (5), 459-462. https://doi.org/10.1130/G32995.1 